This PDF is a selection from an out-of-print volume from the National Bureau of Economic Research

Volume Title: NBER Macroeconomics Annual 1989, Volume 4 Volume Author/Editor: Olivier Jean Blanchard and Stanley Fischer, editors

Volume Publisher: MIT Press

Volume ISBN: 0-262-02296-6

Volume URL: http://www.nber.org/books/blan89-1

Conference Date: March 10-11, 1989

Publication Date: 1989

Chapter Title: Building Blocks of Market Clearing Business Cycle Models

Chapter Author: Kevin M. Murphy, Andrei Shleifer, Robert W. Vishny

Chapter URL: http://www.nber.org/chapters/c10966

Chapter pages in book: (p. 247 - 302) 
Kevin M. Murphy, Andrei Shleifer, and Robert W. Vishny UNIVERSITY OF CHICAGO GRADUATE SCHOOL OF BUSINESS

\section{Building Blocks of Market Clearing Business Cycle Models}

\section{Introduction}

This paper discusses market clearing real business cycle models. In these models, economic fluctuations are characterized by movements along a stable labor supply curve. As a result, real wages and labor input both move together with output. Although the procyclical behavior of real wages has been debated, the current consensus seems to be that real wages are moderately procyclical (Bils 1985; Kydland and Prescott 1988; Solon and Barsky 1988).

There are four separate classes of explanations of procyclical real wages in a decentralized market clearing framework. In the first three explanations, labor productivity is procyclical, and real wages follow productivity. These three explanations can be summarized by writing the production function:

$y(t)=\gamma(t) F(K(t), L(t))$,

where $\gamma$ is the technological shock, $K$ is the capital, $L$ is labor, and $y$ is output at time $t$. Labor productivity at time $t$ can be high if either (a) the productivity shock $\gamma$ is high at time $t$, or (b) the capital stock is high at time $t$, or (c) the labor input is high at time $t$, and production function exhibits increasing returns to scale. The first explanation of high productivity in booms drives the real business cycle theories of Kydland and Prescott (1982), Long and Plosser (1983), and Prescott (1986). The second explanation is the basis of models in which booms result from increases in the capital stock. Shleifer (1986) and Kiyotaki (1988) present examples of such models where increasing returns help generate endogenous fluctuations, but the driving force behind output fluctuations over time is 
really the changes in the capital stock. The third explanation of procyclical productivity is increasing returns in the form of declining marginal cost, either at an industry or an economy-wide level. Murphy, Shleifer, and Vishny (1988) is an example of such a model.

Procyclical productivity is not the only way to generate procyclical real wages; countercyclical markups of price over cost also give this result. In some models (Phelps and Winter 1970; Okun 1981; Stiglitz 1984; Bils 1986), demand becomes less elastic during recessions, perhaps because customers with elastic demand leave the market, and so optimal markups rise. In other models (Weitzman 1982; Solow 1984; Hammour 1988), markets are monopolistically competitive and the price is tied to the average cost which falls in a larger market. As a result, markups fall in the boom and real wages are procyclical. In yet another approach (Rotemberg and Saloner 1986), competition between oligopolists intensifies and markups fall in a boom. In all these models-whether or not they assume increasing returns-procyclical real wages result from countercyclical markups and not from procyclical marginal productivity. These models should be distinguished from those with real wages driven by procyclical productivity.

In this paper, we focus on the comparison of increasing returns (IR) and technological shock (TS) real business cycle models. We spend relatively little time on models driven by changes in the capital stock. Although additions to the capital stock probably raise productivity in the later stages of the boom, capital stock changes cannot explain all of the business cycle, particularly productivity movements during periods and in sectors of no capacity addition. We also do not spend much time on countercyclical markup stories, although we do find them attractive. The main reason for this omission is that our own work has focused on IR models. We also do not deal with models that do not fit into the market clearing framework. Some of the relevant papers (Roberts 1987; Heller 1986) replace perfectly functioning markets with market games; others (Cooper and Haltiwanger 1989) present centrally planned allocations. Finally, we do not focus on models where prices are rigid or costly to change; these models have been surveyed by Rotemberg (1987).

In comparing TS and IR models, we stress that the building blocks that are likely to make these two approaches work are similar, even though the sources of productivity movements are very different. In particular, we identify durable goods, elastic labor supply, specialized labor, and imperfect credit as key assumptions needed to make these models consistent with stylized facts. Although we occasionally criticize existing TS models, our main task is to argue that these models have many implica- 
tions and require assumptions similar to business cycle models with increasing returns.

To fix ideas, in section 2 we present a simple 1-sector IR model based on Murphy, Shleifer, and Vishny (1988) and describe its similarities to and differences from the standard TS model. The emphasis in that section is on the importance of durable goods for generating large output fluctuations without large changes in productivity. The section also shows that business cycles almost have to arise in a model with increasing returns, durable goods, and elastic labor supply. We conclude that the 1-sector IR model can generate the same essential predictions as the TS model, and is consistent with a broader range of evidence.

Although most research on real business cycles has focused on a 1sector model, one of the crucial empirical challenges is to explain the significant amount of co-movement of labor inputs and outputs in different sectors. In Section 3, we first document this co-movement over the business cycle. We then suggest that the TS literature has not adequately explained co-movement, even though this step is necessary to generate aggregate fluctuations from sectoral productivity shocks. Finally, we show how two assumptions-immobility of labor across sectors and imperfect capital markets-help generate co-movement in both TS and IR models. To stress the similarities between the two approaches, we use a TS model to make many of the arguments we previously made in Murphy, Shleifer, and Vishny (1988). The upshot of Section 3 is that with immobile labor and imperfect capital markets TS and IR models can be extended to many sectors.

In Section 4, we deal with the crucial ingredient of both the IR and the TS models: elastic labor supply. We discuss some plausible and implausible reasons why the assumption of elastic labor supply might be valid and the relevance of micro-econometric evidence for this debate.

In Section 5 we present some evidence on the behavior of relative prices over the business cycle. We find that the relative prices of finished goods are much less procyclical than those of raw materials and intermediate goods. Among finished goods, durables appear to have countercyclical relative prices. Finally, output prices are strongly countercyclical relative to input prices. Our evidence for the postwar period basically replicates the findings of Mills (1936) and Means et al. (1939) for the Great Depression, except that real wages in the postwar period have been procyclical and in the 1930s they were countercyclical. This evidence on relative prices is problematic for the view that recessions result from adverse shocks to production functions or prices of common inputs, such as oil or steel. The evidence favors models based on 
increasing returns in distribution or on countercyclical markups on finished durables.

Section 6 concludes.

\section{A 1-Sector Real Business Cycle Model with Increasing Returns}

In this section we outline a 1-sector general equilibrium model of the economy where production is subject to increasing returns to scale. The model is taken from Murphy, Shleifer, and Vishny (1988), hereafter MSV88, which is both more formal and contains considerably more material. After presenting the model, we compare it to the standard TS model.

The model describes fluctuations in a single durable good industry subject to industry-wide increasing returns. Because the good is durable, short run demand for it is extremely elastic, since consumers can easily substitute purchases over time. The industry-wide increasing returns assumption amounts to saying that productivity is high at high industry output and low at low industry output, and that no individual firm can by itself energize the industry and move it to high output and low costs.

The combination of flat short-run demand and downward sloping supply naturally leads to instability in the system. It is efficient for this industry to produce at capacity some of the time and to rest other times, rather than to always produce at a constant output level. More interestingly, even though some output fluctuations are efficient, equilibrium output fluctuations are not. Because the industry cannot coordinate the end of a slump, firms in equilibrium often get stuck at the low output level for periods of time that are much longer than is necessary to take advantage of increasing returns. The fact that the economy gets stuck at a low output level is the essence of the IR theory of economic fluctuations.

\subsection{DEMAND AND SUPPLY}

We consider a model with a representative consumer maximizing the utility function given by:

$\int_{0}^{\infty} e^{-r t}(u(S(t))-L(t)) d t$

where $S(t)$ is the stock of durables the consumer owns at time $t$, and $L(t)$ is his labor supply. The assumption that labor is perfectly (or at least highly) substitutable over time is important; we return to it in Section 4. 
The evolution of the stock of durable goods is given by

$S(t)=X(t)-\delta S(t)$

where $X(t)$ is output at time $t$ and $\delta$ is the depreciation rate.

The durability of the good leads to an important distinction between the long-run and the short-run demand curves. The long-run demand curve for the good, $D(X)$, is given by:

$u^{\prime}(X / \delta)=(r+\delta) p$,

where $p$ is the price of the durable in utility units or leisure units. This demand curve is downward sloping. In the long-run, at a lower price the consumer demands a higher constant stock of durables.

In the short-run, in contrast, the stock of durables is essentially fixed, since the supply and depreciation over an instant are trivial relative to the stock. To calculate the short-run demand curve, we assume that consumers take all future purchases as given. The short-run demand curve is then horizontal, at the level of prices $p(S(t))$ given by the present value of future rental rates $u^{\prime}(S(\tau))$ :

$p(S(t))=\int_{t}^{\infty} e^{-(r+\delta)} \mathcal{u}^{\prime}(S(\tau)) d \tau$

At any price above $p(S(t))$, the consumer buys nothing at time $t$ and consumes leisure; at any price below $p(S(t))$, his instantaneous demand is infinite. This demand curve relies on perfect intertemporal substitutability of leisure.

For simplicity, we consider an industry subject to Marshallian external economies. Assume that there is a unit interval of competitive firms in this industry, each with a production function:

$x=l \cdot f(X)$,

where $x$ is firm's output, $X$ is industry output, and $l$ is the firm's labor input. We assume that each firm faces a capacity constraint, so $l \leq \bar{l}$. We also assume that $f(0)>0$, and $f^{\prime}>0$. The latter is the increasing returns assumption that makes the productivity of each firm an increasing function of industry output.

The Marshallian externalities formulation enables us to treat firms as price takers while incorporating increasing returns into the model. We 
use a competitive formulation both because it is relatively simple and because it underscores the fact that movements in productivity are responsible for fluctuations. Several recent papers (Hall 1986, 1988a; Cooper and John 1988; Cooper and Haltiwanger 1989) have stressed empirically and theoretically the importance of imperfect competition for macroeconomic fluctuations. The assumption of imperfect competition seems to us to serve two functions. First, it can be the source of coordination problems that lead to multiple equilibria. Second, it can be the source of countercyclical markups that lead to procyclical behavior of real wages and therefore to procyclical labor input. Since Marshallian externalities themselves generate coordination problems, and since we focus on productivity movements rather than countercyclical markups as the source of real wage changes, we do not need the assumption of imperfect competition in the exposition, although its inclusion might make the model more realistic.

In a competitive equilibrium of our industry, it must be the case that:

$x=X$,

$f(X)=w / p ，$

where $w / p$ is the real wage. These conditions give us the industry supply curve, defined as the locus of price quantity pairs that can arise as an industry equilibrium. The supply curve subsumes the equilibrium wage, given by the current and future stocks of durables the consumer owns that firms today take as givens. At this equilibrium wage, labor supply is perfectly elastic. Accordingly, industry supply at the real wage $w / p$ is given by:

$X=f^{-1}(w / p)$,

provided that firms are not at the capacity constraint.

Let $X_{H}$ solve

$X_{H}=l f\left(X_{H}\right)$,

so $X_{H}$ is the industry's capacity output. The goods supply curve is then given in Figure 1: it is decreasing from $p=w / f(0)$ at 0 output to $p=w /$ $f\left(X_{H}\right)$ at capacity output, and then has a vertical spike at capacity output. This industry supply curve can be interpreted as the social average cost curve, since: 
$S A C=\frac{w l}{l f(X)}=\frac{p f(X) l}{l f(X)}=\mathrm{p}$.

The combination of this industry supply curve with horizontal short run demand is the source of equilibrium fluctuations in this model.

How do we interpret our downward sloping industry supply curve? We stress that we do not literally believe that technological externalities are an important explanation of cyclical fluctuations. However, the Marshallian externality formulation can be thought of as a reduced form for some things that we do believe to be important, and discuss at some length in MSV88. The most plausible form of industry-wide increasing returns probably has to do with "thick markets" externalities or with the closely related economies of scale in distribution. When the output in the industry is high, there are many customers in the market, and so the probability of a fast match between the seller and the buyer is much higher. Because the selling costs are a significant component of the costs of making the final good, and because these costs plausibly fall when the industry rather than the firm's output rises, we find specification (6) appealing. In this respect, the work most closely related to our specification is Diamond (1982) and Howitt and McAfee (1988).

There are several industry structures that can be thought of in this way. For example, our supply curve can describe an industry such as

Figure 1 SUPPLY

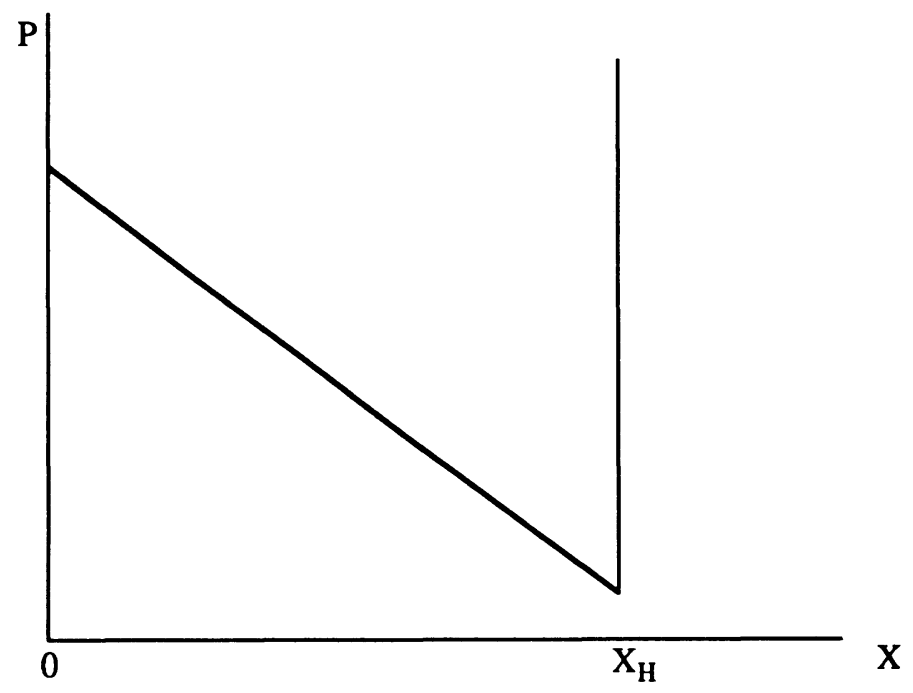


housing in which time to sale falls and therefore productivity rises when there is a lot of construction and many consumers are in the market. Alternatively, our supply curve might be a reduced form description of an industry in which specialized supplies are cheaper when the industry is humming because individual suppliers can take advantage of their increasing returns at the firm level. Our supply curve can also describe an industry in which there are increasing returns in retailing.

An important question is whether our downward sloping supply curve can describe an industry in which markets are perfectly organized, but individual firms face increasing returns in production. Ramey (1987) finds that the industry marginal cost curve for a number of manufacturing industries is declining, suggesting that in fact one can get industry increasing returns purely in production. Ramey also surveys a number of other empirical studies documenting declining industry marginal cost curves. Hall $(1988 \mathrm{a}, \mathrm{c})$ presents evidence for increasing returns at the industry level, although his evidence pertains to decreasing average rather than marginal cost. As we mentioned in the introduction, the decreasing average cost story typically yields procyclical real wages because of countercyclical markups and not because of procyclical productivity. It is thus a different story from the one we tell.

Despite Ramey's and others' evidence on declining industry marginal cost, there are no good theoretical models of such industries. If an industry where individual firms have increasing returns in production adjusts to declines in demand by shutting down inefficient plants, then even if each plant operates subject to increasing returns, industry returns to scale are decreasing. For increasing returns in production at the plant or firm level to translate into industry increasing returns, an industry must contract in a recession by keeping most plants in operation and reducing the output of each, rather than by shutting down inefficient plants. This would be the case if, for example, products of different plants were geographically or otherwise highly differentiated. Contraction of all plants would also result if different firms in the industry could not, for competitive reasons, share the market in a way that enables a few to produce at capacity and to take advantage of increasing returns. Such firms would rather keep their customers and produce at a high marginal cost. However one thinks of these industries, they must have the property that most firms and indeed most plants are marginal and so increasing returns at the plant level translate into increasing returns at the industry level. Since our paper focuses on the structure of increasing returns models, we treat (6) as a primitive assumption and do not pursue a specific model of the market structure. 


\subsection{EQUILIBRIA}

An equilibrium in this model is a path of output $X(t)$, durable stock $S(t)$, wage $w(t)$ and price $p(t)$ such that all markets clear. Note that as long as (5) holds, the consumer is on his labor supply curve.

To make the model interesting, we assume that the long-run demand curve $D(X)$ cuts the downward sloping segment of the supply curve. If $D(X)$ cuts the supply curve at capacity, the equilibrium is the trivial outcome in which all firms produce at capacity all the time. In MSV88 we show that if building capacity is sufficiently cheap relative to the cost saving from operating at a higher output, firms will always build enough capacity so that long run demand curve cuts the downward sloping segment of the supply curve.

This model has a variety of cyclical equilibria, which take the following form. Over some period of time, the economy produces at capacity $X_{H}$, the stock of durables grows, and the rental rate on durables falls. During initial stages of this period, people's willingness to work for goods declines since their consumption rises, and so the price of goods falls while real wages rise. Toward the end of the high production period, the price of goods actually rises in the anticipation of lean times and high rental rates in the future. Eventually the boom ends, and the economy switches to zero output, again maintained over some period of time. During this period, the stock of durables depreciates and the rental rate rises. As consumption falls over this period, the willingness of people to work for goods rises, and at least at the initial stages of the recession prices rise and real wages fall. Toward the end of the recession, we again get the effect that prices fall because people know that good times are coming and with them low rental rates.

This business cycle can be easily thought of in terms of Figure 2 . During the boom, the economy operates on the vertical segment of the supply curve. As the boom continues, the demand curve essentially slides down the vertical segment of the supply curve, because the willingness to work diminishes (again, the demand curve moves up shortly before the boom ends). At some point, the economy switches to zero output, and at the initial stages of the boom the demand curve is moving up. Eventually, the economy goes back to the high production level. Figure 3 describes the behavior of the capital stock, prices, and real wages over the business cycle.

The period of these cycles can be very short, where the economy "chatters" between high and low output, or much longer. In the longer cycles, the sector gets stuck at a high or low output level because a 
coordinated change in output by many firms is required to change each firm's productivity and prices. The Marshallian externality in the production function is the source of this coordination failure. The coordination failure is crucial to the model, since without it the economy would fluctu-

Figure 2 EQUILIBRIUM

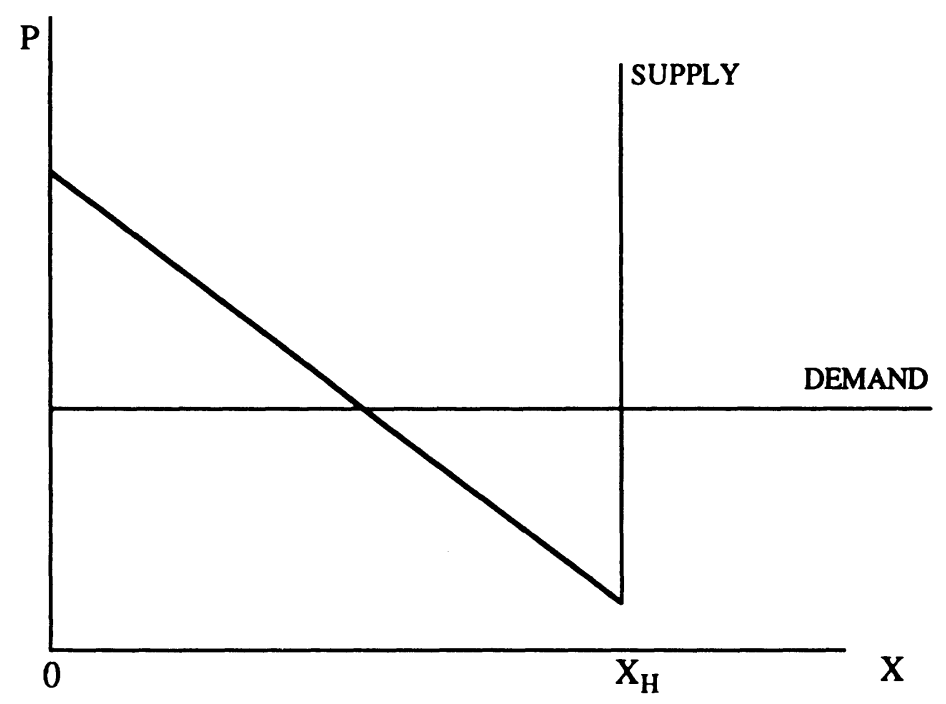

Figure 3 CYCLICAL VARIABLES

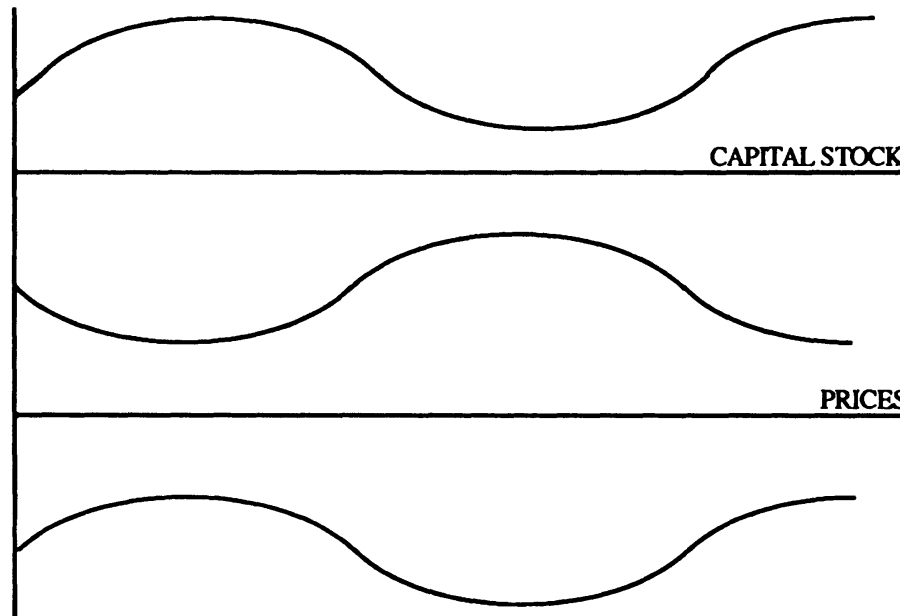


ate at a very high frequency, and there would be no hope of explaining low frequency business cycle fluctuations. Although many cycles are sustainable, constant output is not sustainable as an equilibrium, since in this case any firm raising its output would bring other firms to do likewise and thus destroy the equilibrium.

An interesting property of this model is that it has the cycle of longest possible duration, for reasons detailed by Mitchell (1927). In this cycle, the price of durables reaches its minimum and maximum sustainable values. The longest cycle has the property that both the recession and the boom last as long as they possibly can in a cyclical equilibrium. If the boom were to last any longer, the rental rates would get to be so low that at some point prior to the end of the boom the price of durables would have to fall below production cost even when the sector is operating at maximum efficiency. Because this cannot happen in equilibrium, there is a natural end to the boom, where people get so satiated with durables that they would rather take leisure than work even at a high productivity. In terms of Figure 2, the longest boom can be thought of as the demand curve falling off the cliff at $X_{H}$. Similarly, if the recession were to last any longer, at some point prior to its end the prices of durables would get so high that even one firm operating alone at a low productivity can make money by producing. This of course cannot happen in equilibrium. This natural end to the recession means that people eventually want goods so much that they are willing to work at low productivity to get goods rather than consume leisure. The longest cycle is a form of long-run stability in this economy, which arises because the long-run demand curve for goods is steeper than the long-run supply curve.

The welfare properties of the equilibria in this model can be easily summarized. First, at least some output fluctuations are efficient. It is efficient for this sector to take advantage of increasing returns and to produce some of the time and rest the remainder of the time. Second, most equilibrium fluctuations are not efficient. This inefficiency is reflected in the fact that the period of the cycle is too long, which leads to excessive variability of consumption. The inefficiency is also reflected in the fact that, for a cycle of a fixed period, recessions last too long relative to booms, leading to too low an average level of consumption. The main reason for the latter inefficiency is the Marshallian externality and the resulting coordination problem, that prevents firms from spending more time operating at capacity. The model shows that even in the world where fluctuations of output are efficient, equilibrium business cycles are unlikely to be so. 


\subsection{A COMPARISON OF THE IR MODEL WITH THE TS MODEL}

Similarities: There are a significant number of similarities between the IR model described above and the TS model. Most obviously, fluctuations in both models are driven by productivity movements. In the TS model, such movements result from exogenous technological shocks. In the IR model, they result from endogenous movements along the increasing returns production function. The consequence of either assumption, however, is that business cycles are associated with movements in true, rather than just measured, productivity.

A key feature of our model is durability of the good, that leads to extremely elastic short-run demand and instability. As a result, the model generates large output fluctuations even with small increasing returns. TS models have not stressed durable consumption goods, although they do emphasize the durable nature of capital. The large responsiveness of investment to small changes in productivity is an important element of the Kydland/Prescott and Prescott models as well.

An appealing feature of our model, that can be easily worked into a TS model, is the natural limit on the length of booms and recessions. Proponents of the TS view rarely talk about business cycles per se, and so this issue of mean reversion does not arise. However, the effect we are talking about would appear in a TS model also. Even if the economy is subjected to a sequence of fairly persistent adverse technology shocks, eventually it would pay to work and to produce even if opportunities are poor, provided that people are hungry enough for goods. Such long-run stability would thus appear in a TS model as well.

Differences: Here we note four differences between 1-sector IR and TS models, other than the source of productivity movements. First, the IR model is an endogenous business cycle model, and the TS model is an exogenous shocks model. To the extent that we have trouble identifying technology shocks, particularly the bad ones that cause recessions, an endogenous business cycle model seems more attractive. Moreover, we find the importance of self-fulfilling expectations an attractive feature of the IR models.

Second, most technology shocks are likely to be persistent, whereas periods of production at high capacity in IR models are temporary. Because Prescott (1986) assumes highly persistent shocks, the ability of agents to engage in intertemporal substitution is limited. Hence, intertemporal substitution must be very high to rationalize the observed movements as an equilibrium response to permanent shocks. In contrast, since in our endogenous model good times are very temporary, we need 
much less intertemporal substitution to induce agents to respond to periods of high productivity with increased labor supply. Since intertemporal substitutability needed to calibrate TS models is extremely large, the fact that IR models need much less of such substitutability is attractive.

Third, IR and TS models have different implications about the response of labor productivity to demand shocks. Kydland/Prescott predict that, holding technology constant, labor productivity should fall and certainly not rise in response to a demand shock because of diminishing returns. In contrast, our model predicts that a demand shock could switch the economy to a high output level, and so raise productivity because of increasing returns.

Consistent with the last prediction, Hall (1988c), using instruments for demand disturbances, finds that demand shocks positively affect the Solow residual. The appropriateness of Hall's instruments, which include most notably the price of oil, has been questioned. His results can also be explained by unobserved procyclical work effort. If Hall's results stand up to scrutiny, however, they provide strong evidence against TS models. In an observation similar to Hall's, Mankiw (1987) points out that measured labor productivity rose in World War II, at the time of a sharp increase in the government's purchases of durables. One explanation of Mankiw's result is increasing returns, although there are others, including the increased war effort.

A final distinction between the simple IR and the simple TS models is in the treatment of welfare consequences of fluctuations. Our IR model suggests that the efficiency cost of most business cycles is small, since consumption of durables varies a lot less than do purchases. Empirically, we may not be too far from Prescott's (1986) conclusion that business cycles are efficient. Nonetheless, it seems obvious that neither TS nor IR models have yet dealt with important costs of business fluctuations, such as unequal distribution of the burden of the recessions or their excessive duration because of more fundamental problems, such as financial collapse. It is fair to say that neither approach has seriously dealt with policy.

We can summarize this section by stressing that both models are similar in that fluctuations are driven by movements in labor productivity. Both models are significantly more plausible when they stress durability of goods as a way to generate large output responses to small productivity changes. The increasing returns model has the additional advantage of being supported by independent evidence (Ramey 1987; Hall 1988a,c). In the next few sections, we describe in more detail some of the ways to augment both the standard TS model and our IR model to make them match the evidence better. 


\section{Co-movement of Outputs and Labor Inputs Between Sectors}

\subsection{THE EVIDENCE AND THE PROBLEM}

The previous section has presented a 1-sector IR model of the business cycle and compared it to a 1-sector TS model. One sector models do not, however, address the question of co-movement of outputs and labor inputs across sectors during the business cycle. In this section, we first discuss the fact that such co-movement is extremely pronounced, and is clearly one of the crucial stylized facts that a business cycle model should explain. We then suggest that the Prescott (1986) and Long/Plosser (1983) models do not adequately explain why outputs and labor inputs in different sectors move together. Finally, we present an alternative approach to co-movement, based on immobile (specialized) labor and imperfect credit.

Table 1 presents the evidence on annual correlation of growth rates of different sectors of the economy during 1947-87. Panel A focuses on annual growth rates of real output, and panel B presents data on annual growth rates of employment. Table 1 also includes correlations with changes in detrended employment rate-described in more detail in Section 5-which is our preferred business cycle indicator.

Table 1 shows extremely high correlations of output growth across sectors, as well as high correlations of sectoral growth rates with the business cycle indicator. Most strikingly, the correlation of growth rate of durables with the growth rate of GDP is .95, and with the change in the detrended employment rate it is .92. Growth rates of output in construction, nondurables, and even trade are also extremely highly correlated with the GDP growth rate, the cyclical indicator, and each other. Mining co-moves somewhat less, in part because there is a sharp change in the trend growth rate of mining over this period. Even government and finance seem to move in step with other sectors. In fact, there is not a single negative coefficient in panel A of Table 1 . It is very much the case in these data that outputs in broadly defined sectors move together and procyclically.

A similar picture emerges for labor inputs in panel B of Table 1. Growth rates of labor inputs are highly correlated across sectors, and with the cyclical indicator. Durables again lead the pack, showing a .95 correlation with the growth rate of total employment, and a .93 correlation with the changes in the cyclical variable. There are a few negative correlations of employment growth rates, such as between government and trade and government and services, but by and large employment growth rates behave like output growth rates. In fact, the extent of comovement in labor inputs between durables, non-durables, construc- 


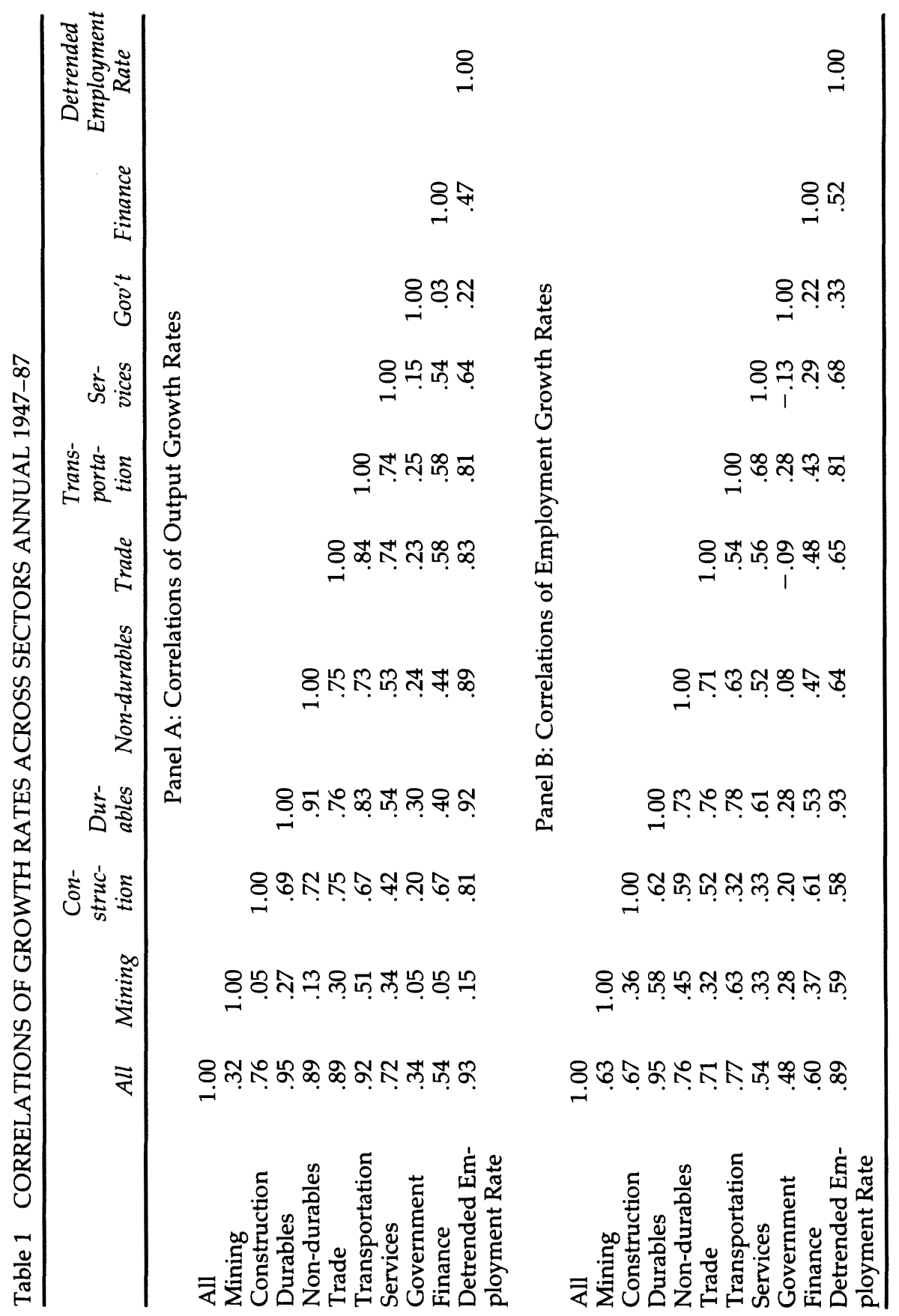


tion, and trade is quite remarkable-and those are the sectors across which labor is potentially mobile.

One question Table 1 does not address is whether co-movement between sectors is just a reflection of trend growth rates in the economy, or whether it reflects shorter-run cyclical fluctuation of sectors. To address this issue, Table 2 presents partial correlations of output and employment growth rates controlling for business cycle movements. In these partial correlations, the business cycle control is our detrended employment growth rate. Large residual correlations would be evidence of strong non-cyclical co-movement, which can just reflect the growth rate of the economy.

The partial correlation coefficients in Table 2 are obviously much smaller than those in Table 1, and many of them are negative. For example, the residual correlation of growth rates of durables and nondurables is .50, compared to the correlation of .91 in Table 1, and the residual correlation of durables and construction is .26 to the correlation of .69 in Table 1. Similarly, the residual correlation of growth rates of durable and non-durable employment is .53, compared to the raw correlation of .73, and the residual correlation of growth rates of employment in durables and construction is -.20 , compared to the raw correlation of .62. In fact, the average difference between the total correlation of sectoral output growth rates with GDP growth and the residual correlation of these two variables is .28. Similarly, the average difference between the total correlation of sectoral employment growth rates with GDP growth rate and the residual correlation is .24. These results demonstrate quite convincingly that cyclical co-movement of growth rates of output and employment across sectors qualifies as a bona fide stylized fact of business cycle analysis.

Theoretically, generating such strong positive co-movements of outputs and labor inputs from sectoral productivity changes is not easy. To see the problem, suppose that sector $A$ is operating at a high level with an increasing returns technology, or has a good technology shock. Either way, productivity and wages in sector A are high, and so, with a positively sloped labor supply curve, labor input in sector A rises. If other sectors do not also experience a productivity improvement, and if the output of sector A is not complementary in consumption or production with the outputs of these other sectors, labor should move out of these sectors and into sector $\mathrm{A}$, resulting in a negative co-movement of labor inputs across sectors. Unless the good productivity shock is pervasive, so that the only sector that shrinks is leisure, this model has trouble explaining co-movement of labor inputs.

This problem is troubling for both Prescott's (1986) and Long and 


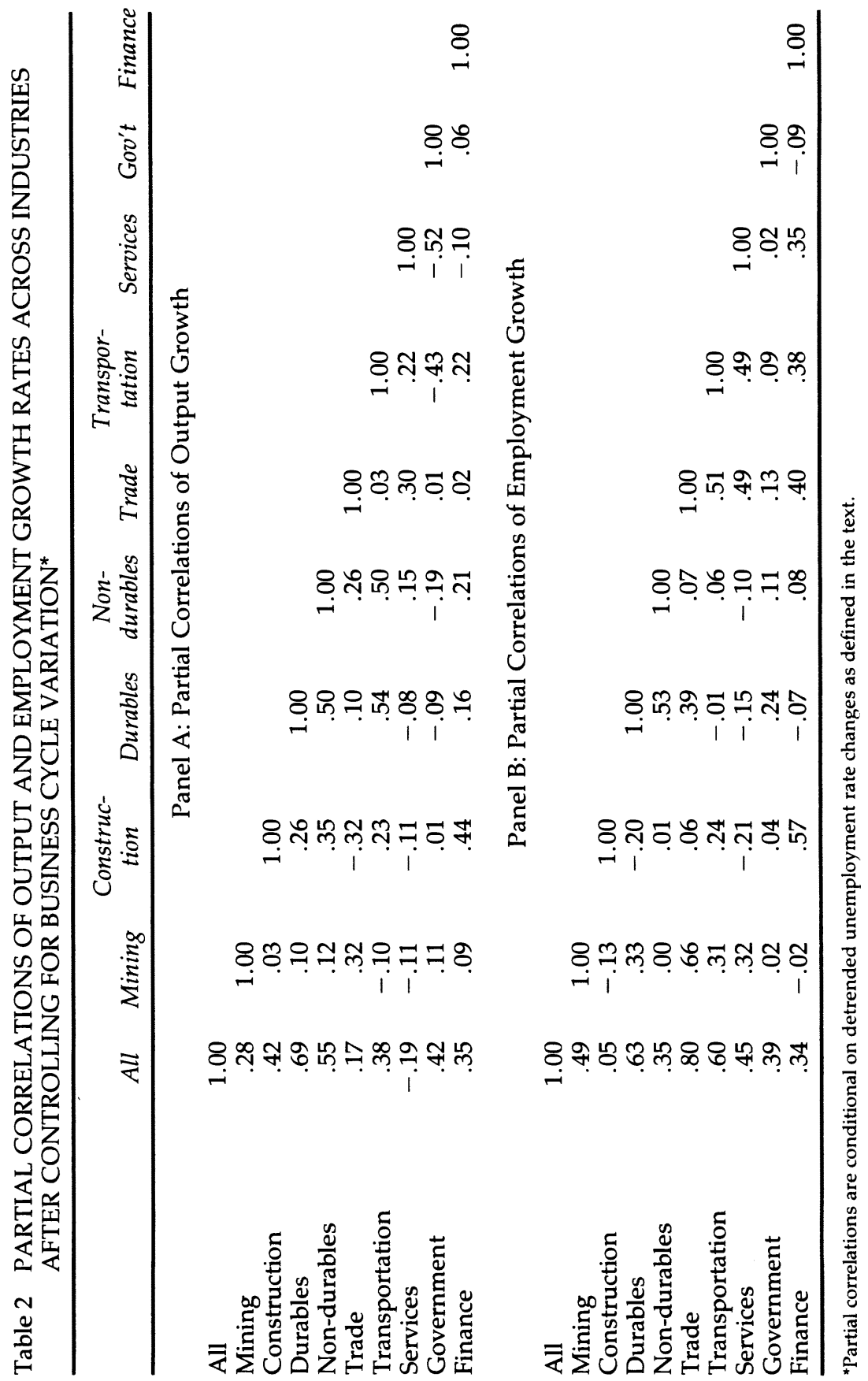


Plosser's (1983) approaches. As has been pointed out independently by Benhabib, Rogerson, and Wright (1988), Prescott's (1986) model predicts a negative co-movement of labor inputs between consumption and investment sectors. Prescott does not distinguish between consumption and investment sectors, but we in fact can think of the two sectors as separate but having identical production functions. Prescott calibrates his model by noting that, in the long run, labor input does not rise and maybe even declines with increases in productivity. This means that, within the consumption sector, the income effect is at least as strong as the substitution effect. The implication of this assumption is that employment in the consumption sector does not rise, and possibly shrinks, in response to a good productivity shock to that sector. From the point of view of employment in the consumption sector, we can therefore think of shocks in this model as being only to the investment good sector.

Suppose there is a good productivity shock to the investment sector. In response to this attractive temporary opportunity, labor input in the investment sector rises, raising the marginal utility of leisure. Calibration says that holding the labor input in the investment sector constant, labor input in the consumption sector is independent of productivity in the consumption sector. Hence, since labor input in the investment sector rises, we should get a fall in the labor input in the consumption sector. The Prescott (1986) model thus predicts, counterfactually, countercyclical labor input in the consumption sector. This result is much more general than Prescott's (1986) specific model; details are available from us upon request.

A similar problem would arise in Long and Plosser's model, except they assume unit elastic demand for leisure. As a result of this assumption, labor inputs do not change over the cycle in their model: their model generates co-movement in outputs at constant labor inputs. If LP instead assumed a more conventional positively sloped labor supply, they would get a negative co-movement of labor inputs between sectors at the time productivity shocks hit. An increase in productivity in one sector raises the real wage and draws labor into that sector out of other sectors as well as out of leisure. Long and Plosser can still get a positive co-movement of final outputs by the time shocks propagate through the input-output matrix. As we show in Section 5, however, this story is inconsistent with relative price evidence.

In the rest of this section, we offer a solution to this problem, based on the idea that, first, labor is specialized and immobile between sectors, and, second, there are borrowing constraints. In practical terms, immobile labor means that people have a strong comparative advantage at working in only one, or a few, sectors, and therefore cannot easily move 
into whatever sector is productive at the moment. This assumption is perfectly consistent with large gross labor flows in the economy, and with a high level of mobility of some segments of the labor force. It only says that, for many workers, it is better to work in their own sector and to exchange the output for other goods than always to move into the most productive sector. Immobile labor creates a need for people to trade the goods they produce, rather than working in each sector to produce the good for their own consumption.

This need to trade when labor is immobile is an important component of the story explaining co-movement. Consider first the case of mobile labor. When sector A is productive, and labor is mobile, it pays all workers to come work in sector A to buy sector A's good, which is now particularly cheap. Unless some other goods are complements to Awhich we assume they are not-the tradeoff between leisure and work in other sectors has not changed. In this case, workers should both consume less leisure and work less in other sectors.

Suppose, in contrast, that outside workers are not trained to work in sector A, so that the increase in sector A's labor input comes entirely from the reduction in leisure of its own workers. Good A is still cheap, and so outside workers want to spend more on it if demand for $A$ is elastic. To do that, they must work more in their own sectors, and then spend more on good $\mathrm{A}$. This leads to increased labor input in other sectors, and a positive co-movement of labor inputs across sectors. Alternatively, workers from outside sector A can borrow and buy more of good A now, working slightly more today and in all the future periods to repay their debts. If workers can easily borrow, there would be some but not much co-movement. Generating significant co-movement between sectors requires both immobile labor and restricted borrowing opportunities.

In the next subsection, we present the immobile labor argument formally using a 1-period TS model. Subsection C summarizes the arguments in MSV88 that use these ideas in an IR model. Our theory of comovement illustrates the importance of trade, as opposed to Robinson Crusoe, for understanding fluctuations. We show at the end of this section that several earlier papers have made assumptions amounting essentially to immobile labor.

\subsection{A FORMAL TS MODEL}

This section presents a one-period competitive RBC model with technological shocks. There is a unit interval of small sectors, each producing its own good, $s$. There is also a unit measure of consumers. The utility function of each consumer is given by 
$\int_{0}^{1} \frac{c(s)^{\theta}}{\theta} d s-\frac{L^{\beta}}{\beta}$

where $c(s)$ is consumption of good $s$ and $L$ is labor. We assume that $\beta \geq 1$ and $\theta \leq 1$. For consistency of the model, we also assume that $\beta-\theta^{2}>0$. In this model, the case of $\theta>1$ corresponds to elastic demand for goods and upward sloping labor supply. The substitution effect in the demand for goods is stronger than the income effect. In contrast, when $\theta<0$, the income effect is stronger, the demand for goods is inelastic, and labor supply is backward bending. Naturally, the case of $\theta>0$ is more plausible for durables. Also note that $\beta=1$ corresponds to no diminishing marginal utility of leisure and $\theta=0$ to the Long/Plosser case of unit elastic demand for goods and therefore for leisure.

The production function of good $s$ is given by

$y(s)=\gamma(s) L(s)$,

where $\gamma(s)$ is technological shock and $L(s)$ is labor input in sector $s$. Each good is produced competitively in its own sector.

Consider first this model with mobile labor, so there is actually a representative consumer we can talk about. This consumer's budget constraint is given by

$\int c(s) p(s) d s=L w$.

Market clearing requires that $c(s)=y(s)$ for all $s$, and competition says that $\gamma(s) p(s)=w$. We can let the wage be numeraire: $w=1$.

This model can be solved for consumption of each good $s$ and labor input in each sector $s$ as a function of technological shocks in all sectors:

$$
\begin{aligned}
& c(s)=\gamma(s)^{\frac{1}{1-\theta}}\left[\int\left(s^{\prime}\right)^{\frac{\theta}{1-\theta}} d s^{\prime}\right]^{\frac{1-\beta}{\beta-\theta}} \\
& L(s)=\gamma(s)^{\frac{\theta}{1-\theta}}\left[\int \gamma\left(s^{\prime}\right)^{\frac{\theta}{1-\theta}} d s^{\prime}\right]^{\frac{1-\beta}{\beta-\theta}}
\end{aligned}
$$

Several observations can be made about these solutions.

First, consumption of good $s$ always increases in $\gamma(s)$. This is because a good productivity shock always reduces the relative price of good $s$, and since $s$ is normal, its consumption rises. Second, when $\theta>0$, labor input in sector $s$ rises with the technology shock, and when $\theta<0$, labor input declines with the shock. The former case corresponds to the elastic de- 
mand for good $s$, so when the price of good $s$ falls, demand for $s$ rises more than the increase in output due to the productivity increase, and so employment rises. Conversely, when $\theta<0$, the demand for good $s$ is inelastic, and so a rise in productivity leads to a less than proportional increase in the quantity consumed, and so a reduction in the labor input. The case of $\theta>0$ corresponds to durable goods, and so both labor and output should probably rise when a sector experiences a positive productivity shock.

More interesting results concern co-movement of outputs and labor inputs across sectors. When $\beta=1,(15)$ and (16) show that all sectors move by themselves, without any influence from other sectors, as one would expect in the case of separability of goods and no increasing disutility of work. The same result obtains in the Long/Plosser case of $\theta$ $=0$, where labor inputs in different sectors are fixed, and outputs move proportionately with productivity because of unit elastic demand. Except for these two cases, however, labor always negatively co-moves between sectors. When $\theta>0$, a good productivity shock in sector $s^{\prime}$ raises demand for labor in $s^{\prime}$, and so, since the tradeoff between employmen $i$ in sector $s$ and leisure has not changed, there will be a reduction both in leisure and in employment in $s$. When $\theta<0$, a good productivity shock to $s^{\prime}$ reduces labor input in $s^{\prime}$ because of inelastic demand for this good, and so labor moves both into leisure and into sector $s$. This case, of course, is blatantly inconsistent with the evidence. In either case, labor inputs in $s$ and in $s^{\prime}$ move in opposite directions, contrary to what happens over a business cycle.

Furthermore, output negatively co-moves in the plausible case of $\theta>$ 0 , and positively co-moves with $\theta<0$. When $\theta>0$, a good shock in $s^{\prime}$ raises employment and output in $s^{\prime}$ but cuts employment in $s$, as we mentioned earlier. Because productivity in sector $s$ is unchanged, output of good $s$ must also fall. Output in $s$ and $s^{\prime}$ thus move in opposite directions. When $\theta<0$, a good shock in $s^{\prime}$ raises output but reduces employment in $s^{\prime}$. Because labor moves into sector $s$, both employment and output in sector $s$ rise. This leads to co-movement of outputs. In the case of mobile labor, we thus get two unrealistic results: employment comoves negatively, and output co-moves negatively in the plausible case of upward sloping labor supply. Long and Plosser do not get the latter result because, in their model, shocks are to common intermediate inputs and so are correlated.

Consider next the more interesting case of immobile labor, where a worker can only work in one sector or consume leisure. We assume the same preferences as before, and the same number of workers per sector. 
Let $c\left(s, s^{\prime}\right)$ be consumption of good $s$ by a worker in sector $s^{\prime}$. The budget constraint of worker $s^{\prime}$ now takes the form:

$\int c\left(s, s^{\prime}\right) p(s) d s=L\left(s^{\prime}\right) w\left(s^{\prime}\right)$

for all $s^{\prime}$. Competition now does not restrict wages to be the same in all sectors:

$\gamma(s) p(s)=w(s)$

for all s. Finally, market clearing takes the form

$\int c\left(s, s^{\prime}\right) d s=\gamma(s) L(s)$

for all $s$. For our purposes, we do not need to choose a numeraire.

A considerable amount of grinding leads to the following closed form solution to this model:

$$
\begin{aligned}
& w(s)=\gamma(s)^{\frac{\theta(\beta-\theta)}{\beta-\theta^{2}}} \quad(20) \\
& p(s)=\gamma(s)^{\frac{\beta(\theta-1)}{\beta-\theta^{2}}}(21) \\
& c\left(s, s^{\prime}\right)=\gamma\left(s^{\prime}\right)^{\frac{\theta \beta}{\beta-\theta^{2}}} \cdot \gamma(s)^{\frac{\beta}{\beta-\theta^{2}}}\left[\int \gamma\left(s^{*}\right)^{\frac{\beta \theta}{\beta-\theta^{2}}} d s^{*}\right]^{\frac{\beta-1}{\theta-\beta}} \\
& L\left(s^{\prime}\right)=\gamma\left(s^{\prime}\right)^{\frac{\theta^{2}}{\beta-\theta^{2}}}\left[\int \gamma\left(s^{*}\right)^{\frac{\beta \theta}{\beta-\theta^{2}}} d s^{*}\right]^{\frac{1-\theta}{\beta-\theta}}
\end{aligned}
$$

Using (22)-(23), we can ask the same questions as we did with mobile labor.

Similar to the case with mobile labor, consumption of good $s$ by a worker in sector $s^{\prime}$ increases both in the shock to sector $s$ and in the shock to sector $s^{\prime}$. But there are some crucial differences. First, because of the symmetry assumption, labor input in sectors always rises with productivity in that sector, whether or not $\theta$ is positive. When $\theta>0$, demand for good $s$ is elastic. At the same labor input as before the shock, the price of good $s$ declines less than productivity rises, so that the real wage in sector $s$ rises. Since labor supply is upward sloping for $\theta>0$, labor input rises in response to the increase in the real wage. In contrast, when $\theta<$ 0 , demand for good $s$ is inelastic. When $\gamma(s)$ rises, $p(s)$ falls more than the productivity increase, and so the real wage in sector $s$ falls. But labor supply slopes down for $\theta<0$, and so labor input rises in response to the fall in the real wage. Independent of the value of $\theta$, labor input in sector $s$ always moves in the same direction as productivity in that sector. 
The most interesting results again concern co-movement of labor inputs and of consumption. In this model, we get co-movement of labor inputs as long as $\theta>0$. When productivity $\gamma\left(s^{\prime}\right)$ in sector $s^{\prime}$ rises, $p\left(s^{\prime}\right)$ falls, which raises the real wages of workers in all other sectors. With $\theta>$ 0 , labor supply in these sectors slopes up and so workers there all work more. Conversely, with $\theta<0$, labor supply slopes down and labor input in sector $s$ falls in response to a rise in $\gamma\left(s^{\prime}\right)$. As long as workers want to work more when their real wage rises, they respond to a lower price in another sector by producing more of their own good, and trading it for the productive sector's output.

Co-movement of consumption, like co-movement of labor, depends on the sign of $\theta$. When sector $s$ experiences a good productivity shock, $p(s)$ falls and real wages in all sectors rise. When $\theta>0$, workers in all sectors want to work more and to buy more of all goods, so consumption of all goods rises. In contrast, when $\theta<0$, the response to a rise in real wages from a fall in $p(s)$ is to work less, so hours and consumption of all goods other than good $s$ fall. Consumption of different goods co-moves, therefore, as long as labor supply slopes up.

The results for mobile and immobile labor are very different. With mobile labor, employment always co-moves negatively across sectors, and consumption co-moves only if $\theta<0$. With immobile labor, employment and consumption both co-move for $\theta>0$ and not otherwise. The reason for the difference is that with mobile labor, one can get more of another good by working in the sector in which it is produced, whereas with immobile labor one has to work in one's own sector and trade. For durables, the case of elastic demand (and therefore positively sloped labor supply) is the empirically correct one. Since in this case the model clearly generates empirically correct predictions about co-movement of labor inputs and consumption over the business cycle, the case for assuming specialization and immobile labor seems to be compelling.

Because our model assumes identical demand elasticities for different goods, it does not deal with Prescott's case. We have looked at a model where $\theta=0$ for one good, and $\theta>0$ for another. In such a model, one indeed gets a negative co-movement of labor inputs with mobile labor, and a positive co-movement with immobile labor.

So far we have presented a one period model, and have not addressed the issue of credit. If we think of some of the goods in our model as future consumption goods, the credit point is apparent. Even if labor is immobile, an increase in productivity and the resulting decline in the price of good $s$ is likely to lead to only a small increase in today's labor input in other sectors. Instead of working much harder today, a worker in a sector $s^{\prime}$ would borrow to take advantage of the low price of good $s$, 
and repay the loan by raising his labor supply today and in all the future periods by a small amount. To generate a significant amount of comovement between sectors, both immobile labor and imperfect credit are required.

The role we have assigned to imperfect credit here is different fromand complementary to-that in other recent models (Bernanke and Gertler 1989; Greenwald and Stiglitz 1987). In those models, a bad shock reduces the internal availability of funds to a firm, which then has to reduce its investment because of the credit constraint. The reduction in investment in turn leads to lower output and therefore a persistently lower availability of funds in the future. Importantly, this is basically a 1sector (or one-firm) story of the role of credit. In contrast, here and in MSV88 credit serves to facilitate intertemporal trade between sectors. When credit markets are imperfect, such trade is less attractive, leading agents in different sectors of the economy to synchronize their production periods so they can trade instantaneously and economize on credit. In this sense, imperfect credit in our model serves to concentrate the effects of shock at a point in time rather than to spread them over time. We believe that both consequences of imperfect credit are important in practice. In fact, it may be possible to combine the Greenwald-StiglitzBernanke-Gertler view of countercyclical costs of credit with some features of our model, such as immobile labor, durables and elastic labor supply, to generate self-fulfilling fluctuations even in the absence of increasing returns at the sectoral level.

\subsection{CO-MOVEMENT IN A MODEL WITH INCREASING RETURNS}

So far, we have considered the co-movement issue in a TS model, where it is simpler to see. Identical arguments apply also in a variant of an IR model of Section 2, and are developed in MSV88. The question in the IR model is: why wouldn't different sectors of the economy cycle out of sync with each other, especially if there is an aggregate resource constraint? If they do cycle out of sync, aggregate output would be smooth, and we would not observe aggregate fluctuations.

In MSV88, we show that aggregate fluctuations obtain when labor is immobile and borrowing is constrained. In this case, when a sector is productive and its output is cheap, the only way workers in other sectors can take advantage of low prices is by working themselves and trading their output for the productive sector's output. In equilibrium, all sectors fluctuate together. As in a TS model, aggregate fluctuations obtain with immobile labor and restricted borrowing in an IR model.

The notion of immobile labor has appeared in a number of recent models in somewhat different ways. Diamond (1982), Weitzman (1982), and 
Roberts (1987) assume either that workers are specialists in production and generalists in consumption, or that they cannot consume the good that they produce. The power of this assumption is always to make trades necessary for consumption and to preclude the possibility that people, like Robinson Crusoe, simply toil to produce their own consumption good. The point that MSV88 and the current paper emphasize is that these assumptions can be used to explain the observed co-movement of outputs and of labor inputs across sectors in a wide range of models. Specialization does not just generate "Keynesian" results, but also yields empirically correct predictions about co-movement-even in a TS model. There is nothing intrinsically Keynesian about specialization. ${ }^{1}$

\section{Elastic Labor Supply}

\subsection{THE NEED FOR ASSUMING ELASTIC LABOR SUPPLY}

Recent empirical research (Bils 1985; Kydland and Prescott 1987; Solon and Barsky 1988) finds that real wages move procyclically over the business cycle, but only mildly so. At the same time, to generate large labor supply movements from small changes in real wages, one needs to assume that the intertemporal or lifetime elasticity of labor supply is much higher. For example, Prescott (1986) takes this elasticity to be 2, and still predicts too-low fluctuations in hours.

Even if one believes that real wages are installment payments that do not reflect underlying productivity, and do not really serve to allocate labor over the business cycle, one still needs a fairly elastic labor supply. The effects of both technology shocks and increasing returns over the business cycle are probably small quantitatively. To get large efficient movements in the labor input in response to such small changes in technology requires easy substitutability of labor over time. That is, for workers and firms to agree to a contract that requires large changes in their labor input in response to small changes in productive opportunities, leisure must be easily substitutable over time. Otherwise, one needs to explain why the worker and the firm do not eliminate inefficient fluctuations in hours that are not justified by fluctuations in productivity.

We have pointed out earlier that TS models with reasonably persistent technology shocks require a greater labor supply elasticity than do IR models to generate the same fluctuations. This is because in an IR model, periods of high productivity are by definition temporary, since it

Scheinkman and Weiss (1986) assume immobile labor and imperfect credit to generate a role for money as a store of value. They do not consider the role of immobile labor in generating co-movement of outputs and of labor inputs across sectors. 
is not an equilibrium to produce high output all the time. In contrast, in a TS model driven by reasonably permanent shocks, good opportunities to work are equally permanent, and so the instantaneous labor supply response to a shock is small. Because productivity changes are less permanent in an IR model, the labor supply elasticity required by such a model is smaller.

At the same time, whereas a TS model depends on elastic labor supply only quantitatively, an IR model fails to generate fluctuations altogether if labor supply is sufficiently inelastic. In a TS model, less elastic labor supply dampens the effects of technological shocks on output, and consequently reduces output volatility. In our model, in contrast, sufficiently inelastic labor supply can eliminate the possibility of fluctuations altogether. The reason is that when labor supply is sufficiently inelastic, increases in industry output raise costs even if labor productivity rises, and so make the supply curve slope up rather than down. If the supply curve slopes up, the unique stable equilibrium is constant output. In this way, inelastic labor supply completely eliminates the possibility that our model can explain business cycle fluctuations.

As this subsection suggests, even though TS and IR models rely in different ways on the elastic labor supply assumption, they both rely on it strongly. More generally, any model that fits the observed fluctuations of labor input must rely on this assumption. For example, it is needed for countercyclical markup models, since the decline in markups must more than compensate for the rise in costs in a boom. Keynesian rigid wage models also rely on elastic labor supply to the extent that the cost of setting wages flexibly must be large to explain the costly fluctuations in hours. Below we offer a few comments on plausibility of elastic labor supply.

\subsection{THE PLAUSIBILITY OF ELASTIC LABOR SUPPLY}

Although the macroeconomic models described above require an elasticity of labor supply of at least 1 or 2, the elasticity estimated from micro data is extremely low, perhaps around .3. The reason for this low estimate is that wages and hours for a given individual are both highly variable, and are basically uncorrelated. Put differently, the coefficient of the regression of the change in hours on the change in wages, just as that of the regression of the change in wages on the change in hours, is close to zero. The fact that there are many reasons why measured hours and wages change, unrelated to the labor supply elasticity, is undoubtedly responsible for the low estimate of this elasticity in micro data. This observation has led a number of researchers to try to reconcile the low labor supply elasticity obtained from micro studies with a high elasticity needed to explain the macro evidence. 
One recent approach, begun by Rogerson (1988), starts with the observation that there may be important non-convexities in the labor supply decision, such as transportation costs. This model then says that people take leisure in the recession because it is not efficient for everyone to incur these fixed costs of going to work when productivity is low.

We have two reservations about this approach. First, it relies on the assumption that all individuals are identical. If there is heterogeneity of individuals' costs of going to work, then changes in the wage would get a few marginal people to discretely change their labor supply decision, but would not affect hours for inframarginal workers. It is by no means clear that the resulting aggregate labor supply curve is more elastic than it is when fixed costs are absent. For a similar reason, the fact that the decision to eat Chinese food on a particular day is discrete does not mean that the intertemporal elasticity of substitution for Chinese food is infinite. Second, fixed costs of going to work should equally affect both the micro and macro estimates of labor supply elasticity. It is not correct to say that micro evidence yields true preference parameters, since micro estimates are also affected by fixed costs. This approach cannot then explain the inconsistency between micro and macro evidence. Although non-convexities might be part of the explanation of elastic labor supply, they do not reconcile micro and macro evidence.

There seem to be some more plausible ways to explain why hours change a lot over the business cycle when wages change only a little. One obvious possibility in the later period is unemployment insurance with high replacement rates and imperfect experience rating, which should significantly raise the effective elasticity of labor supply. The second possibility is that people with a high intertemporal elasticity of substitution should sort themselves into cyclically sensitive industries. That is, people who like to work hard some of the time and rest other times have a strong comparative advantage at working in durable sectors, where employment volatility is expected. Third, the reason that hours respond strongly to small changes in wages may be that wages are simply installment payments in a long-term relationship and do not serve to allocate labor over the short-run. Finally, it may be the case that the employer gets to choose employment at some fixed wage and so effectively faces an elastic labor supply even though leisure is not easily substitutable over time. On the surface, such a rigid Keynesian wage model looks very similar to a model with a perfectly elastic labor supply (Hall 1988b) except with distinctly different welfare implications.

To summarize, market clearing models of economic fluctuations require an intertemporal labor supply elasticity of at least 1 or 2 , but micro estimates are much smaller. However, micro evidence is not informative 
on the intertemporal elasticity of labor supply because it is hard to identify temporary wage changes at the individual level. Trying to reconcile micro and macro evidence may not, therefore, be necessary. A more fruitful approach might be to understand why the true elasticity is high or, alternatively, why wages are rigid.

\section{The Behavior of Relative Prices}

\subsection{OVERVIEW}

In this section, we present evidence on the behavior of relative prices of different commodity groups over the business cycle. We then interpret this evidence in light of IR, TS as well as countercyclical markup models of economic fluctuations.

IR and TS models make very strong predictions about the behavior of relative prices. Both models say that goods produced with low productivity are expensive relative to goods produced with high productivity. Since low productivity is associated with recessions, the models say that in the recession the relative price of goods experiencing a productivity decline should rise. This implication leads to a natural question: what are the goods that become relatively more expensive in the recession? By isolating these goods, we can find the nexus of technology shocks or increasing returns.

We consider several commodity groups and ask three questions: (1) What is the cyclical behavior of the prices of finished goods, intermediate goods, and raw materials relative to the GNP deflator and to the private sector wage? (2) What is the difference in the cyclical behavior of the prices of durable and non-durable goods relative to the GNP deflator and to the private sector wage? (3) How do the relative prices of outputs and inputs move over the cycle? Answers to these questions can give us some information about the nexus of increasing returns, technology shocks, and countercyclical markups.

\subsection{THE EVIDENCE}

This section presents the evidence on the cyclical behavior of relative prices. All the data for this study are annual for 1947-87, taken from the 1988 Economic Report of the President. Our cyclical indicator is constructed from the civilian unemployment rate. To make the regression coefficients interpretable, we rescale this variable before using it in the regression. First, we pass a spline in time through the unemployment rate starting in 1965 to control for changes in the natural rate of unemployment, and then take the residuals. Second, we first difference the 
resulting series and take the negative of such obtained changes. This gives us a procyclical measure, equal to detrended changes in the employment rate. In each business cycle, we define a boom as the year of the fastest growth rate of (detrended) employment, and a recession as the year of the smallest growth rate of (detrended) employment. Finally, we scale these detrended growth rates of employment so that the average over all cycles of the difference of growth rates of employment between boom and recession is equal to .01. That is, in an average cycle, our detrended and normalized employment grows $1 \%$ faster in the year defined as a boom than in the year defined as a recession. This cyclical indicator is presented in Figure 4, where vertical lines denote recessions. Importantly, the peaks and troughs of this indicator coincide with peaks and troughs in the growth rate of output.

In addition to using the Normalized Detrended Growth Rate of Employment in the analysis, we also use a dummy equal to 1 in 1974 and 1975, and 0 in all the other years. We do so because the 1974-75 recession has been accompanied by a large and very unusual change in relative prices. In particular, the relative price of oil and derivative products has increased significantly. The 1980 recession also exhibits this pattern of relative

Figure 4

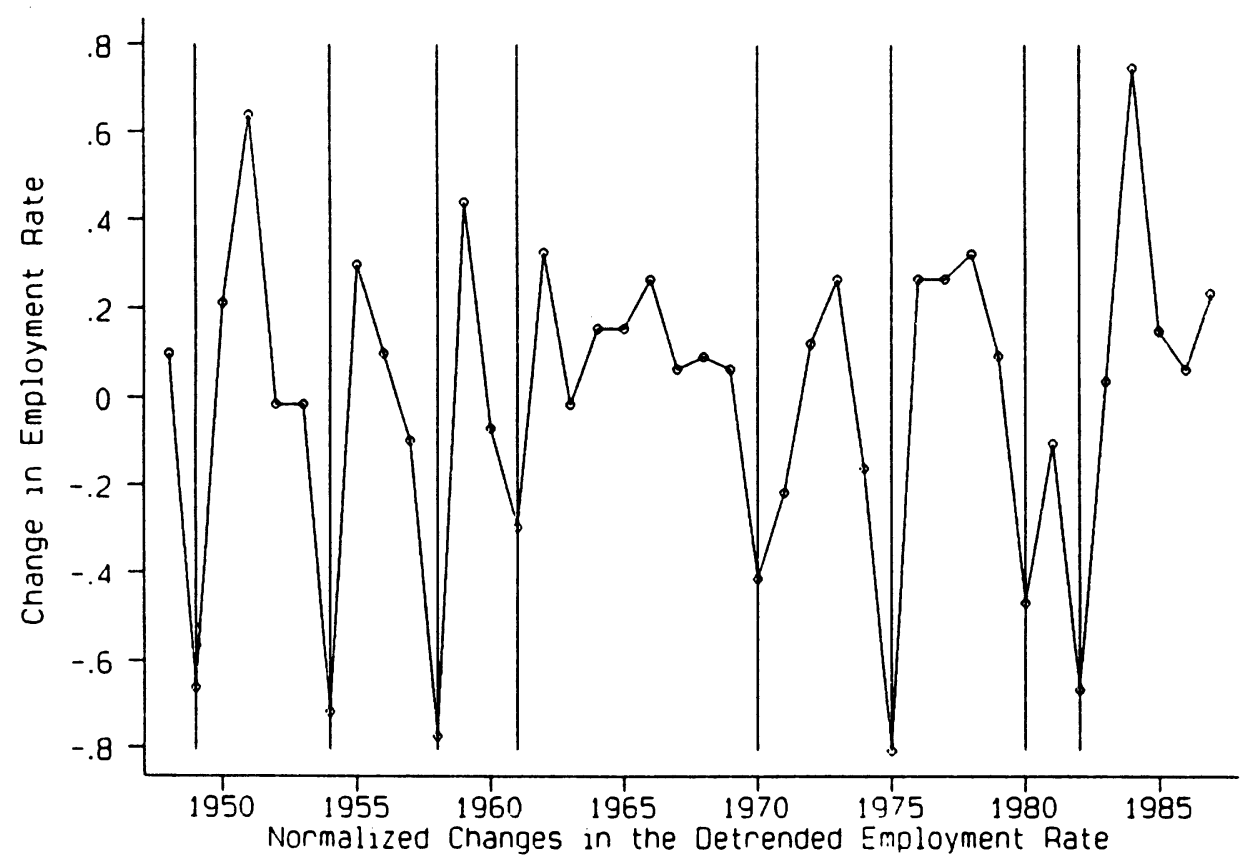


prices, but it is not as pronounced. Because the 1974-75 recession looks so different from all the others but one, we did not want to contaminate our inference by this episode. All the regressions we run take the form

Change in relative price $=A+B \times($ Cyclical Indicator $)+C \times(1974-1975$ dummy).

Tables 3-5 present the results. Table 3 presents the evidence on prices relative to the GNP deflator. Table 4 presents the results on prices relative to the average private sector hourly earnings. Table 5 presents the evidence on relative prices. In all tables, panel A deals with broad groups of goods by stage of processing, and panel B deals with individual commodities. Based on the scaling of the cyclical indicator, all the coefficients in the tables are easy to interpret. For example, the coefficient in the finished goods regression in panel A of Table 3 is .79. This means that, relative to the GNP deflator, prices of finished goods on average change $.79 \%$ more in a boom (the year of the fastest increase in the employment rate for each cycle) than in the recession (the year of the lowest change in the employment rate for each cycle). The coefficient of 4.54 on the 1974-75 dummy in this regression means that the price of finished goods rose $4.54 \%$ per year faster relative to GNP deflator in 1974-75 than in other periods.

In interpreting the results of Tables 3-5, we refer to relative prices that yield a positive coefficient on the cyclical indicator as procyclical, and relative prices that yield a negative coefficient as countercyclical. The regression coefficient measures the difference in the growth rate of relative prices between the boom (defined as the year of fastest growth rate of detrended employment in each cycle) and the recession (defined as the year of the lowest growth rate of detrended employment in each cycle). The reason we need such a relative measure is that some prices follow strong trends, and so may, for example, fall relative to the GNP deflator in both booms and recessions. If the relative price does not have a trend, a positive regression coefficient would say that, the relative price rises in a boom and falls in a recession. If, in contrast, the relative price is always falling, a positive coefficient would say that it falls less in the boom than it does in a recession. Either way, the relative price is procyclical in the sense that relative to how they do in a recession, relative prices rise in a boom. The same logic explains why negative regression coefficients correspond to countercyclical relative prices.

Two kinds of results emerge from Table 3 . First, finished goods do not show much cyclical behavior relative to the GNP deflator, except for slightly countercyclical relative price changes of finished durables. In 
Table 3 CYCLICAL BEHAVIOR OF PRICES RELATIVE TO GNP DEFLATOR

\begin{tabular}{|c|c|c|}
\hline Variable & $\begin{array}{l}\text { Cyclical } \\
\text { Indicator }\end{array}$ & $\begin{array}{l}\text { 1974-75 } \\
\text { Dummy }\end{array}$ \\
\hline \multicolumn{3}{|c|}{ Panel A: Broad Groups by Stage of Processing } \\
\hline Finished goods & $\begin{array}{c}.79 \\
(.92)\end{array}$ & $\begin{array}{c}4.54 \\
(3.20)\end{array}$ \\
\hline Consumer durables & $\begin{array}{c}-.77 \\
(-1.00)\end{array}$ & $\begin{array}{c}.78 \\
(.61)\end{array}$ \\
\hline Consumer non-durables & $\begin{array}{c}.37 \\
(.23)\end{array}$ & $\begin{array}{c}7.38 \\
(2.76)\end{array}$ \\
\hline Capital equipment & $\begin{array}{c}-.81 \\
(-1.00)\end{array}$ & $\begin{array}{c}4.37 \\
(3.26)\end{array}$ \\
\hline Total intermediate & $\begin{array}{c}2.69 \\
(2.09)\end{array}$ & $\begin{array}{c}8.87 \\
(4.16)\end{array}$ \\
\hline Manufacturing materials & $\begin{array}{c}3.32 \\
(2.54)\end{array}$ & $\begin{array}{l}10.47 \\
(4.83)\end{array}$ \\
\hline Construction materials & $\begin{array}{l}3.05 \\
(3.41)\end{array}$ & $\begin{array}{c}5.69 \\
(3.84)\end{array}$ \\
\hline Fuels & $\begin{array}{l}1.31 \\
(.36)\end{array}$ & $\begin{array}{l}21.4 \\
(3.52)\end{array}$ \\
\hline Crude Materials & $\begin{array}{c}9.91 \\
(2.44)\end{array}$ & $\begin{array}{l}4.59 \\
(.68)\end{array}$ \\
\hline \multicolumn{3}{|c|}{ Panel B: Commodities } \\
\hline Power & $\begin{array}{l}.59 \\
(.15)\end{array}$ & $\begin{array}{l}22.04 \\
(3.34)\end{array}$ \\
\hline Chemicals & $\begin{array}{c}1.78 \\
(1.18)\end{array}$ & $\begin{array}{l}18.94 \\
(7.58)\end{array}$ \\
\hline Lumber & $\begin{array}{l}10.58 \\
(4.11)\end{array}$ & $\begin{array}{l}-3.69 \\
(-.87)\end{array}$ \\
\hline Paper & $\begin{array}{l}3.53 \\
(2.62)\end{array}$ & $\begin{array}{l}10.07 \\
(4.52)\end{array}$ \\
\hline Metals & $\begin{array}{l}3.65 \\
(2.39)\end{array}$ & $\begin{array}{c}9.70 \\
(3.83)\end{array}$ \\
\hline Machinery & $\begin{array}{c}-.67 \\
(-.70)\end{array}$ & $\begin{array}{c}4.81 \\
(3.05)\end{array}$ \\
\hline Household durables & $\begin{array}{l}-.20 \\
(-.29)\end{array}$ & $\begin{array}{c}2.08 \\
(1.79)\end{array}$ \\
\hline Vehicles & $\begin{array}{c}-2.08 \\
(-2.03)\end{array}$ & $\begin{array}{l}.11 \\
(.07)\end{array}$ \\
\hline Rubber & $\begin{array}{c}4.05 \\
(1.67)\end{array}$ & $\begin{array}{c}8.89 \\
(2.22)\end{array}$ \\
\hline
\end{tabular}

Note. $t$-statistics in parentheses. 
Table 4 CYCLICAL BEHAVIOR OF PRICES RELATIVE TO AVERAGE HOURLY EARNINGS OF PRIVATE-SECTOR EMPLOYEES

\begin{tabular}{|c|c|c|}
\hline Variable & $\begin{array}{l}\text { Cyclical } \\
\text { Indicator }\end{array}$ & $\begin{array}{l}\text { 1974-75 } \\
\text { Dummy }\end{array}$ \\
\hline \multicolumn{3}{|c|}{ Panel A: Broad Groups by Stage of Processing } \\
\hline Finished goods & $\begin{array}{c}.29 \\
(.30)\end{array}$ & $\begin{array}{c}6.35 \\
(3.98)\end{array}$ \\
\hline Consumer durables & $\begin{array}{c}-1.27 \\
(-1.72)\end{array}$ & $\begin{array}{c}2.59 \\
(2.12)\end{array}$ \\
\hline Consumer nondurables & $\begin{array}{l}-.13 \\
(-.08)\end{array}$ & $\begin{array}{c}9.19 \\
(3.29)\end{array}$ \\
\hline Capital equipment & $\begin{array}{c}-1.31 \\
(-1.65)\end{array}$ & $\begin{array}{c}6.18 \\
(4.69)\end{array}$ \\
\hline Total intermediate & $\begin{array}{c}2.19 \\
(1.63)\end{array}$ & $\begin{array}{l}10.68 \\
(4.80)\end{array}$ \\
\hline Manufacturing materials & $\begin{array}{c}2.82 \\
(2.08)\end{array}$ & $\begin{array}{l}12.28 \\
(5.47)\end{array}$ \\
\hline Construction materials & $\begin{array}{c}2.55 \\
(2.99)\end{array}$ & $\begin{array}{c}7.50 \\
(5.30)\end{array}$ \\
\hline Fuels & $\begin{array}{l}.82 \\
(.22)\end{array}$ & $\begin{array}{l}23.2 \\
(3.76)\end{array}$ \\
\hline Crude Materials & $\begin{array}{c}9.41 \\
(2.29)\end{array}$ & $\begin{array}{l}6.40 \\
(.94)\end{array}$ \\
\hline \multicolumn{3}{|c|}{ Panel B: Commodities } \\
\hline Power & $\begin{array}{l}.09 \\
(.02)\end{array}$ & $\begin{array}{l}23.85 \\
(3.59)\end{array}$ \\
\hline Chemicals & $\begin{array}{l}1.28 \\
(.79)\end{array}$ & $\begin{array}{l}20.75 \\
(7.73)\end{array}$ \\
\hline Lumber & $\begin{array}{l}10.08 \\
(4.01)\end{array}$ & $\begin{array}{l}-1.88 \\
(-.45)\end{array}$ \\
\hline Paper & $\begin{array}{l}3.03 \\
(2.13)\end{array}$ & $\begin{array}{l}11.88 \\
(5.05)\end{array}$ \\
\hline Metals & $\begin{array}{c}3.15 \\
(2.07)\end{array}$ & $\begin{array}{l}11.52 \\
(4.57)\end{array}$ \\
\hline Machinery & $\begin{array}{c}-1.17 \\
(-1.24)\end{array}$ & $\begin{array}{c}6.62 \\
(4.23)\end{array}$ \\
\hline Household durables & $\begin{array}{c}-.70 \\
(-1.06)\end{array}$ & $\begin{array}{c}3.90 \\
(3.54)\end{array}$ \\
\hline Vehicles & $\begin{array}{l}-2.58 \\
(-2.55)\end{array}$ & $\begin{array}{c}1.92 \\
(1.15)\end{array}$ \\
\hline Rubber & $\begin{array}{c}3.55 \\
(1.42)\end{array}$ & $\begin{array}{l}10.71 \\
(2.59)\end{array}$ \\
\hline
\end{tabular}


contrast, prices of intermediate goods other than fuels are highly procyclical. For example, in an average cycle manufacturing materials grow $3.32 \%$ faster relative to the GNP deflator in a boom than in a recession. One exception to this is capital equipment, which may be thought of as an intermediate good, and which shows mildly countercyclical prices. By far the most procyclical are the prices of crude materials. In an average cycle, crude materials prices rise $9.91 \%$ more relative to the GNP deflator in a boom than they do in a recession. The procyclicality of prices clearly declines as one gets further in the production chain.

Similar results come from the more narrowly defined commodities. As is well known, prices of lumber, metals, paper, and rubber are extremely procyclical. In contrast, prices of finished durable goods, including household durables, machinery, and vehicles are countercyclical. Commodities such as power and, surprisingly, chemicals do not show much action over the cycle.

Table 4 confirms the results of Table 3 , except that the evidence is a little stronger. Relative to the private sector average hourly earnings, prices of finished goods do not show any cyclical behavior except that durables and capital equipment are more clearly countercyclical. Relative prices of raw materials and intermediate goods are, in contrast, strongly procyclical, except for capital equipment. Durable goods, such as household durables and vehicles, show the opposite pattern. Tables 3 and 4 show very clearly that the place to look for productivity declines in the recession is finished durable goods. Table 4 also suggests that procyclical real wages are most pronounced in terms of durables-a finding common to real wage studies.

Table 5 presents some more novel results, namely those on relative prices. The conclusion of Table 5 is that, in the production chain, the relative price of outputs to inputs is countercyclical. For example, relative to intermediate materials, finished goods grow $1.9 \%$ less in the boom than in the recession. Relative to crude materials, this number is $9.1 \%$. Throughout this table, the result is that prices of finished goods are countercyclical relative to intermediate goods and crude materials, and prices of intermediate goods are countercyclical relative to crude materials.

Similar results emerge from panel B of Table 5. Relative to the price of lumber, those of construction materials and household durables move countercyclically. Relative to the price of manufacturing materials, those of vehicles, household durables, and machinery also move countercyclically. Relative to the price of metals, those of vehicles, machinery, household durables are again countercyclical. It is very clear 
from this table that the price of outputs relative to that of inputs is countercyclical.

We draw three conclusions from Tables 3-5. First, the more finished are the goods, the less procyclical are their relative prices. Second, the goods that exhibit the most countercyclical relative prices are durables. Third, outputs appreciate relative to inputs in the recession. Importantly, these results are very similar to those found for the Great Depression period by Mills (1936) and Means et al. (1939) for a broader range of commodities. However, in the Great Depression, real wages actually increased, and so these findings can be rationalized by the observation that the relative price of goods with a greater labor content should be higher. Our starting point, in contrast, is that in the postwar period real wages have been if anything procyclical. Our next task is to interpret our findings for the postwar period.

\section{Table 5 CYCLICAL BEHAVIOR OF RELATIVE PRICES}

\begin{tabular}{lrc}
\hline & Cyclical & $1974-75$ \\
Variable & Indicator & Dummy \\
\hline
\end{tabular}

Panel A: Broad Groups by Stage of Processing

Finished goods/Total intermediate

$-1.90-4.33$

Finished goods/Fuels

$(-2.96) \quad(-4.07)$

$-.53-16.85$

Finished goods/Crude materials

$(-.17) \quad(-3.25)$

$-9.12-.052$

Consumer durables/Total intermediate

$(-2.61) \quad(-.009)$

$-3.46 \quad-8.09$

Consumer durables/Manufacturing materials

$(-2.77) \quad(-3.91)$

$\begin{array}{ll}-4.09 & -9.69\end{array}$

Consumer non-durables/Total intermediate

$(-3.32) \quad(-4.74)$

$-2.32 \quad-1.49$

Consumer non-durables/Manufacturing materials

$(-2.57)$

$-2.96-3.09$

Capital equipment/Total intermediate

$(-2.57) \quad(-1.62)$

$-3.50 \quad-4.50$

Capital equipment/Manufacturing materials

$(-2.72) \quad(-2.11)$

$-4.13-6.10$

$(-3.24) \quad(-2.89)$

Total intermediate/Crude materials

$-7.22 \quad 4.28$

Manufacturing materials/Crude materials

$(-2.37)$

$-6.59 \quad 5.88$

Construction materials/Crude materials

$(-2.08)$

$-6.86$ 


\subsection{INTERPRETATION}

The evidence in Tables 3-5 allows us to discriminate at least partially between various business cycle stories. One story-which we associate with Long and Plosser (1983) - is that technology shocks occur in the production of widely used raw materials or intermediate inputs, and then spread across the economy through the input-output matrix. These shocks need not even be technology shocks; they can simply be price shocks to inputs supplied from outside the economy, like oil. An IR version of this theory says that increasing returns are in the production of raw materials or intermediate goods. As a result, these are the activities experiencing major productivity declines in the recession. Both TS and IR versions of this story predict that the relative price of raw materials and/or intermediate goods is countercyclical.

Table 5 CYCLICAL BEHAVIOR OF RELATIVE PRICES (CONTINUED)

\begin{tabular}{lcc}
\hline & Cyclical & $1974-75$ \\
Variable & Indicator & Dummy \\
\hline \multicolumn{1}{c}{ Panel B: Broad Groups and Commodities } & & \\
Total intermediate/Metals & -.96 & -.83 \\
& $(-.92)$ & $(-.48)$ \\
Manufacturing materials/Metals & -.33 & .77 \\
& $(-.37)$ & $(.52)$ \\
Construction materials/Metals & -.60 & -4.01 \\
& $(-.58)$ & $(-2.33)$ \\
Construction materials/Lumber & -7.53 & 9.38 \\
& $(-3.46)$ & $(2.61)$ \\
Vehicles/Manufacturing materials & -5.40 & -10.36 \\
& $(-3.14)$ & $(-3.63)$ \\
Household durables/Manufacturing materials & -3.52 & -8.39 \\
& $(-3.26)$ & $(-4.68)$ \\
Machinery/Manufacturing materials & -3.99 & -5.66 \\
& $(-3.31)$ & $(-2.83)$ \\
Vehicles/Metals & -5.73 & -9.59 \\
& $(-3.37)$ & $(-3.41)$ \\
Machinery/Metals & -4.32 & -4.89 \\
& $(-3.17)$ & $(-2.17)$ \\
Household durables/Metals & -3.85 & -7.62 \\
& $(-2.92)$ & $(-3.49)$ \\
Capital equipment/Metals & -4.46 & -5.33 \\
Household durables/Lumber & $(-3.27)$ & $(-2.36)$ \\
& -10.78 & 5.77 \\
& $(-4.01)$ & $(1.30)$ \\
\hline
\end{tabular}


This story is inconsistent with the evidence in Tables 3-5. The tables confirm the standard finding that the relative prices of raw materials are extremely procyclical. An exception might be the case of oil in 1974-75 and 1979-80. However, except in these episodes, it is clear that recessions are not driven by adverse shocks or endogenous productivity declines in raw materials or in intermediate goods. This fact also poses a problem for the Long/Plosser theory of co-movement, which works through shocks to common inputs.

The evidence in Tables 3-5 is much more favorable to the view that productivity changes occur at the latter stages of the production process, particularly in durable goods. The IR version of the story says that increasing returns occur in the final stages of production or distribution of durables or possibly at the stage of producing capital equipment. The productivity of these stages declines in the recessions, and therefore the relative price of durables rises. The reason that relative price movements are so pronounced for wide categories of goods is that the co-movement mechanism outlined in the previous section leads to synchronization of output and productivity movements across sectors.

The TS version of this story is somewhat different, and harder to reconcile with the evidence. In the TS world, the goods that get expensive in the recession are only the goods experiencing adverse technology shocks, and not the goods whose output declines simply because of comovement. This is an important difference between IR and TS models: even though both generate co-movement with immobile labor and imperfect borrowing, the TS model exhibits countercyclical price movements only in the sectors with bad shocks. In contrast, the IR model yields relative price increases in all increasing returns sectors in response to output declines. To reconcile the TS model with the evidence, to bring on a recession one needs fairly widespread adverse technology shocks in either the finished durable goods sectors or in the capital equipment sector. We leave to the reader to evaluate the plausibility of pervasive adverse technology shocks in durable goods sectors as a cause of recessions.

Before concluding this section, we stress that the evidence in Tables $3-$ 5 is also broadly consistent with countercyclical markups at the later production stages, especially in durables. None of the evidence we have presented bears on the behavior of true productivity; all the action might well be in markups. Hall's (1988a) earlier evidence can be interpreted in terms of countercyclical markups, although his later (1988c) work points to true increasing returns. As we mentioned before, however, Hall finds evidence of declining average costs and firms earning close to zero profits. This finding points to countercyclical markups as a way to generate procyclical real wages. Domowitz, Hubbard, and Petersen (1988) present 
some evidence bearing on this issue, and conclude that markups are countercyclical. At this point, we are not sure which theory is right and leave this issue to a further investigation.

In summary, the evidence presented in this section enables us to at least partially narrow down the range of theories consistent with the data. If economic fluctuations are driven by technology shocks, these must be pervasive shocks across durable good industries, and not in intermediate input industries. If fluctuations are driven by increasing returns, these must be in the production and distribution of durable goods. Finally, fluctuations could be explained by countercyclical markups in durable good industries, without productivity movements.

\section{Conclusion}

In this paper we have discussed models of business cycles driven by movements of productivity. In particular, we have compared models in which these productivity movements result from exogenous technology shocks with models in which they result from endogenous movements along an increasing returns production function. We asked what kinds of assumptions these models require to at least roughly fit the data. We have found that although these models have very different sources of productivity changes, the assumptions required to fit the data are very similar. First, to generate large movements in output in response to small changes in productivity, these models rely on durability of goods. Second, to produce co-movement of outputs and labor inputs across various sectors of the economy, these models need to assume specialized (immobile) labor and restricted borrowing. Third, to obtain large movements in labor inputs in response to small changes in real wages or productivity, these models require very elastic labor supply. Although none of these results is completely new, we hope that our emphasis on identifying the critical building blocks of a market clearing model proves useful.

Our paper has also documented the countercyclical behavior of prices of outputs relative to inputs, and of finished durables relative to wages and to the GNP deflator. This evidence suggests that the place to look for technology shocks or increasing returns is at the final stages of production, or in the distribution of durable goods. In the increasing returns framework, this evidence supports illiquid markets models of recessions. In these models, time to sale is long and therefore the marginal cost is high in the recession. The fact that such variable liquidity costs are most plausible for durable goods is evidence favorable to this approach.

There are three topics that are closely related to the issues we have 
discussed, but that we have not dealt with for lack of space. The first is downward rigid real wages as an alternative to elastic labor supply. Even if one assumes downward rigid real wages, one still needs a source of productivity changes - such as increasing returns or technology shocksto generate shifts in labor demand. Downward rigid real wages would probably exacerbate the recession in a model of the sort we described, because firms might shut down even when they would not with a flexible real wage. Downward rigid real wages also make the co-movement story look more like an aggregate demand story: instead of changes in relative prices we get changes in income and in demand for individual goods. It remains to be explored what are some of the other consequences of this assumption.

We have also ignored what is perhaps the most natural explanation of our evidence on cyclical behavior of relative prices: countercyclical markups without productivity changes. There are a number of reasons why producers of durables in a recession might not want to cut prices even if marginal costs fall when input prices decline. Most plausibly, we think that the customer mix shifts in the recession away from buyers with elastic demand, and so the profit maximizing markup rises. This change of customer base might occur because most people would require enormous price concessions to buy durables in a recession. The only remaining customers are those who need to replace durables that have fallen apart and so have inelastic demand. The change in the customer base might also occur if people who shop around and therefore have elastic demand are precisely the ones who have very low reservation prices in the recession-they may be individuals who face the risk of unemployment or firms fearing bankruptcy. Such theories of countercyclical markups, developed in particular by Phelps/Winter (1970), Okun (1981), Stiglitz (1984), Bils (1986), Weitzman (1982), and Solow (1984), can probably explain most of our evidence. Not surprisingly, one can build an endogenous business cycle model driven by countercyclical markups without productivity changes.

Finally, all of our discussion has assumed a fixed capital stock in production. In contrast, technology shocks models incorporate capital in the production function. Capital in these models serves in part as a propagation device, whereby today's technology improvements lead to an increase in the capital stock and therefore labor productivity tomorrow. There are also increasing returns models in which a business cycle is generated by movements in the capital stock (Shleifer 1986; Kiyotaki 1988). In these models, waves of investment raise productivity and income, and so lead to increased demand for goods. The higher demand 
for goods in turn justifies the initial investment outlay. Unifying the increasing returns models discussed in this paper with increasing returns investment models remains a stopic for future work.

We are grateful to Olivier Blanchard, Peter Diamond, and Larry Katz for helpful comments and to the NSF for financial support.

\section{REFERENCES}

Bernanke, Ben and Mark Gertler. "Agency Costs, Net Worth, and Business Fluctuations." American Economic Review. Forthcoming 1989.

Benhabib, Rogerson, and Wright. "Home Production and Aggregate Models of the Labor Market." November 1988. Mimeo.

Bils, Mark J. "Real Wages over the Business Cycle: Evidence from Panel Data." Journal of Political Economy 93: 666-89. August 1985.

Bils, Mark J. "Cyclical Pricing of Durable Luxuries." Mimeo. 1986.

Bils, Mark J. "The Cyclical Behavior of Marginal Cost and Price." American Economic Review 77: 838-55. December 1987.

Cooper, Russell and John Haltiwanger. "Macroeconomic Implications of Production Bunching: Factor and Final Demand Linkages," University of Iowa. Mimeo. January 1989.

Cooper, Russell and Andrew John. "Coordinating Coordination Failures in Keynesian Models." Quarterly Journal of Economics 103: 441-64. August 1988.

Diamond, Peter A. "Aggregate Demand in Search Equilibrium." Journal of Political Economy 90: 881-94. October 1982.

Domowitz, Ian, R. Glenn Hubbard, and Bruce C. Petersen. "Market Structure and Cyclical Fluctuations in U.S. Manufacturing." Review of Economics and Statistics 70: 55-66. February 1988.

Greenwald, Bruce and Joseph Stiglitz. "Financial Market Imperfections and Business Cycles." Stanford University. Mimeo. 1987.

Hall, Robert E. "Market Structure and Macroeconomic Fluctuations." Brookings Papers on Economic Activity: 285-322. 1986.

Hall, Robert E. "The Relation between Price and Marginal Cost in U.S. Industry." Journal of Political Economy 96: 921-47. October 1988a.

Hall, Robert E. "Substitution over Time in Consumption and Work." Stanford University. Mimeo. June $1988 b$.

Hall, Robert E. "Increasing Returns: Theory and Measurement with Industry Data." Stanford University. Mimeo. September 1988c.

Hammour, Mohamad. "Increasing Returns and Endogenous Business Cycles." Cambridge, Mass.: MIT Press. Mimeo. March 1988a.

Hammour, Mohamad. "Are Business Cycles Endogenous?" Cambridge, Mass.: MIT Press. Mimeo. November $1988 b$.

Heller, Walter P. "Coordination Failure under Complete Markets with Application to Effective Demand." in Equilibrium Analysis: Essays in Honor of Kenneth J. Arrow. vol. 2, W. Heller, R. Starr, and D. Starrett. eds. Cambridge: Cambridge University Press, 1986.

Howitt, P. and R. P. McAfee. "Stability of Equilibria with Externalities." Quarterly Journal of Economics 103: 261-277. May 1988. 
Kiyotaki, Nobukiro. "Multiple Expectational Equilibria under Monopolistic Competition." Quarterly Journal of Economics 103: 695-714. November 1988.

Kydland, Finn and Edward Prescott. "Time to Build and Aggregate Fluctuations," Econometrica 50: 1345-700. November 1982.

Kydland, Finn and Edward Prescott. "Cyclical Movements of the Labor Input and Its Real Wage." Federal Reserve Bank of Minneapolis, Mimeo. November 1988.

Long, John and Charles Plosser. "Real Business Cycles." Journal of Political Economy 91: 36-39. February 1983.

Mankiw, N. Gregory. "Real Business Cycles: A Neo-Keynesian Perspective." Journal of Economic Perspectives. Forthcoming.

Means, Gardiner C., et al. The Structure of the American Economy. Washington, D.C.: United States National Resource Committee. 1939.

Mills, Frederick C. Prices in Recession and Recovery. New York: NBER. 1936.

Mitchell, Wesley. Business Cycles: The Problem and Its Setting. New York: National Bureau of Economic Research. 1927.

Murphy, Kevin M., Andrei Shleifer, and Robert W. Vishny. "Increasing Returns, Durables, and Economic Fluctuations." University of Chicago. Mimeo. October 1988.

Okun, Arthur. Prices and Quantitites: A Macroeconomic Analysis. Washington, D.C.: The Brookings Institution. 1981.

Phelps, Edmund and Sidney Winter. "Optimal Price Policy under Atomistic Competition." in Microeconomic Foundations of Employment and Inflation Theory. E. Phelps, ed. New York: W. W. Norton, 1970.

Prescott, Edward. "Theory Ahead of Business Cycle Measurements." reprinted in Federal Reserve Bank of Minneapolis, Quarterly Review. 9-22. Fall 1986.

Ramey, Valerie. "Non-Convex Costs and the Behavior of Inventories." University of California at San Diego. Mimeo. December 1987.

Roberts, John. "An Equilibrium Model with Involuntary Unemployment at Flexible, Competitive Prices and Wages." American Economic Review 77: 856-74. December 1987.

Rogerson, Richard. "Indivisible Labor, Lotteries and Equilibrium." Journal of Monetary Economics 21: 3-17. 1988.

Rotemberg, Julio. "The New Keynesian Microfoundations." NBER Macroeconomics Annual. 69-104. 1987.

Rotemberg, Julio and Garth Saloner. "A Supergame-Theoretic Model of Price Wars during Booms," American Economic Review 76: 390-407. June 1986.

Scheinkman, Jose A. and Laurence Weiss. "Borrowing Constraints and Aggregate Economic Activity." Econometrica 54: 23-46. January 1986.

Shleifer, Andrei. "Implementation Cycles." Journal of Political Economy 94: 116390. December 1986.

Solon, Gary and Robert Barsky. "Real Wages over the Business Cycles." University of Michigan. Mimeo. 1988.

Solow, Robert. "Monopolistic Competition and the Multiplier." Cambridge, Mass.: MIT Press. 1984. Mimeo.

Stiglitz, Joseph. "Price Rigidities and Market Structure." American Economic Review 7: 350-55. May 1984.

Summers, Lawrence. "Some Skeptical Observations on Real Business Cycle Theory." Federal Reserve Bank of Minneapolis, Quarterly Review. 23-27. 1986. 
Weitzman, Martin L. "Increasing Returns and the Foundation of Unemployment Theory." Economic Journal 92: 787-804. 1982.

\section{Comment}

EDWARD C. PRESCOTT

Federal Reserve Bank of Minneapolis and the University of Minnesota

Over the last two decades much progress has been made in macroeconomics. Using established theory-that is the theory used by leading people in public finance-we have found that variations in the Solow technology parameter are an important source of aggregate fluctuations in the postwar period. Business cycles are not an anomaly for standard neoclassical theory. The methodology employed is quantitative neoclassical theory. The model economies are calibrated to national income and product accounts and household surveys. Equilibrium policy rules for the economic agents are computed and then used to determine the sampling distribution of various statistics.

Subsequent to Kydland and my "Time to Build" paper, a number of issues have been explored with this methodology. For example, Cooley and Hansen (1988) have explored the implications of a cash-in-advance constraint for aggregate fluctuations. They found that they were not very important. Danthine and Donaldson (1989) have come to similar conclusions with regard to the introduction of an efficiency wage construct. Huffman, Greenwald, and Hercowitz (1988) have studied the behavior of economies in which the capital depreciation rate increases with the intensity with which capital is utilized. Again, the consequences for aggregate fluctuations were minor. Hansen and Sargent (1988) found that introducing both a straight time and overtime work options significantly enriches the theory but does not alter the finding that the Solow technology shocks are an important source of fluctuations.

\section{What Does Matter?}

Hansen (1985) introduced the Rogerson (1988) labor indivisibilities and found it did matter and did matter a lot for business cycle accounting. It also mattered for assessing the importance of public finance shocks which recently have been explored by Christiano and Eichenbaum (1988), Chang (1988), Braun (1988), and McGratten (1988) using this methodology. If both the hours a plant is operated and the number of workers that operate a plant are choice variables, the results are essen- 
tially the same as for the Hansen economy with the labor indivisibility. Most the variation in aggregate hours is accounted for by changes in the number employed. Changes in the hours worked per employed person accounts for the rest of the variation in the aggregate labor input. Hall (1988) surveys the evidence on the intertemporal substitution of leisure and comes to the conclusion that in the aggregate leisure is highly intertemporally substitutable. Given this property, any relatively permanent change in a factor that affects the steady state of the deterministic growth model will contribute to aggregate fluctuations. The question is how much each contributes.

\section{What are the Justifications for Static Marshallian Increasing Returns?}

The key feature of the Murphy-Shleifer-Vishny paper is their introduction of a production externality. The authors assume it and refer to a more rigorous paper in which the underlying micro foundations of such a structure are developed. I examined the cited paper and found the argument heuristic and incomplete, and not yet up to the standards of modern general equilibrium theory. What are the theoretical justifications for these static increasing returns at the industry level but not at the firm level? One justification for Marshallian increasing industry returns is Arrow's learning-by-doing. But, this is a dynamic relation. It is not temporary increases in the average product of labor at the firm level that are associated with temporary increases in industry output as in the Murphy-Shleifer-Vishny model. Another justification for industry increasing returns is induced technological change. Jacob Schmookler (1966) has presented evidence for demand induced technological change. But that also is a dynamic story. Changes are permanent. What is the empirical evidence for static industry increasing returns to scale? How big are they? Where are the measurements? Do Chrysler's costs decline when Ford is producing more automobiles? Maybe, but I want to see some evidence before taking the assumption seriously.

One question that has not yet been addressed within the quantitative theoretical framework is whether the findings are sensitive to the assumption of price-taking behavior. Does abstracting from the fact that the corner drugstore has some monopoly power significantly bias the estimate of the importance of Solow technology shocks-or for that matter the importance of public finance shocks, terms of trade shocks, etc.? This is an interesting question. I do not know how to answer it, and it is not an easy question to answer. The theory of monopolistic competition 
in dynamic stochastic environments is not well developed. In the growth literature there are a couple of deterministic models, but typically they are steady-state or balanced growth models. I, however, would be surprised if a little ex post monopoly power necessitated a significant revision in the estimate of the importance of Solow technology shocks as a source of aggregate fluctuations.

One empirical embarrassment for increasing returns stories is that hours of employment and productivity should move together. They do not. At the business cycle frequencies, the correlation is about -0.2 (see Christiano and Eichenbaum 1988). There surely are errors in measuring the labor input and as a result the correlation is larger than -0.2 , but it is a lot less than one. If technology shocks were the only source of fluctuations, standard theory implies that this correlation would be near 1.0. But we do not claim that these shocks are the only source. All that Finn Kydland and I argue is that they are a major source and that the economy would be almost as volatile if they were the only source. Incidentally, when defense expenditure went from 5 to 13 percent of GNP at the beginning of the Korean War, productivity did not jump. It fell.

The authors claim that an implication of standard theory is that employment in the consumption-good producing and investment-good producing sectors should move in opposite directions if technology shocks are the only source of fluctuations. For the Hansen economy (1985) this is not the case. Employment in the consumption-good industry stays constant given that in the aggregate leisure is infinitely substitutable (as it is in the Murphy-Shleifer-Vishny economy). If leisure is durable, as it is in Kydland and my models (1982 and 1988), employment can be procyclical. It is for the Kydland and Prescott (1988) model economy. The authors say Kydland and I assume the shocks are persistent. That is wrong. I, and Nelson and Plosser earlier (1982), found that they were highly persistent. It is an empirical finding-not an assumption.

Why did productivity fall in coal mining in the Seventies if there were increasing industry returns? There was an increase in output in that industry during that period. People in that industry did not know why productivity fell. One coal mining company funded a study at CarnegieMellon (Goodman and Leyden (1985)) to find out the reason for the decline-a decline associated with an increase in output. There are random, that is, currently unpredictable, changes in production functions. This is a fact.

The authors report the finding that output and employment changes are correlated across industries. This was known-see Burns and Mitchell (1947). Is there a close association between quarterly changes in employment and output per workers? I doubt it. Determining industry 
output and inputs on a quarterly basis is fraught with problems. Even at the annual level it is not easy. Jorgenson, Gallop, and Fraumeni (1987) find that productivity changes are correlated and do not average out. If they did average out, there would not be any aggregate shocks and an implication of standard theory would be that Solow technology shocks are not an important source of fluctuations.

At the low frequencies Bailey and Gordon (1988) have concluded that a productivity slowdown has indeed occurred. They point out that the slowdown is across most of the industries. With increasing returns why did productivity growth slow even though output growth did not slow? The reason that output growth did not decline, even though productivity growth did, is that the growth rate of employment increased. This observation matches poorly with the implication of the Murphy-ShleiferVishny model with its implication that employment and productivity move together. To summarize, the static increasing returns has not been justified. Economics has come a long way since the Thirties when business cycle stories were a dime a dozen-see Godfrey Haberler's (1937) book, Prosperity and Depression, for a plethora of them. I hope we do not go back to the Thirties when theory had no quantitative discipline.

The final point of these comments is that standard theory should be used to address specific questions. In challenging Kydland and my finding, the authors are challenging the findings of Jorgenson and Yun (1988) concerning the 1986 tax reform and a lot of other findings that use established theory. I do not think that the authors have made much of a case for using production functions that display static increasing returns. I will stick with Solow's (1957) neoclassical theory for studying business cycle fluctuations until someone develops a better alternative. What determines the rate of technology change is another matter. There I conjecture increasing returns are important.

Prepared for NBER Annual Conference on Macroeconomics. Organized by Olivier Jean Blanchard and Stanley S. Fischer, held March 10 and 11, 1989 Cambridge, Massachusetts.

\section{REFERENCES}

Bailey, M. W. and R. J. Gordon. 1988. “The Productivity Slowdown, Measurement Issues, and the Explosion of Computer Power." Brookings Papers on Economic Activity 2, 347-420.

Boldrin, M. and L. Montrucchio. 1985. “On the Indeterminacy of Capital Accumulation Paths." University of Rochester Working Paper.

Braun, R.A. 1988. "The Dynamic Interaction of Distortionary Taxes aand Aggregate Variables in Postwar U. S. Data." Northwestern University Working Paper.

Burns, A. F. and W. C. Mitchell. 1947. Measuring Business Cycles. New York: NBER. 
Chang, L. J. 1988. “Corporate Taxes, Disaggregated Capital Markets and Business Cycles." Carnegie-Mellon University Working Paper.

Christiano, L. J. and M. Eichenbaum. 1988. "Is Theory Really Ahead of Measurement? Current Real Business Cycle Theory and Aggregate Labor Market Fluctuations." Federal Reserve Bank of Minneapolis Working Paper 412.

Cooley, T. F. and G. D. Hansen. 1988. "The Inflation Tax and the Business Cycle." UCLA Working Paper.

Danthine, J. P. and J. B. Donaldson. 1989. "Efficiency Wages and the Business Cycle Puzzle." Columbia Graduate School of Business Working Paper.

Goodman, P. S. and D. P. Leyden. 1985. Human Resource Management Skill and Coal Mine Productivity_Final Repoort. Vol. 2. Pittsburgh: U.S. Bureau of Mines.

Greenwald, J., Z. Hercowitz, and G. W. Huffman. 1988. "Investment, Capacity Utilization and the Business Cycle." American Economic Review 78: 402-18.

Haberler, G. 1937. Prosperity and Depression. Geneva: League of Nations.

Hall, R. E. 1988. "Substitution over Time in Work and Consumption." NBER Working Paper.

Hansen, G. D. 1985. "Indivisible Labor and the Business Cycle." Journal of Monetary Economics 16: 309-28.

Hansen, G. D. and T. J. Sargent. 1988. "Straight Time and Overtime in Equilibrium." Journal of Monetary Economics 21: 281-308.

Jorgenson, D. W., F. M. Gallop, and B. M. Fraumeni. 1987. Productivity and U. S Economic Growth. Cambridge, Mass.: Harvard University Press.

Jorgenson, D. W. and K. Y. Yun. 1988. "Tax Policies and U.S Economic Growth." Harvard University Working Paper.

Kydland, F. E. and E. C. Prescott. 1982. "Time to Build and Aggregate Fluctuations." Econometrica 50: 1345-70.

Kydland, F. E. and E. C. Prescott. 1988. "The Workweeks of Capital and its Cyclical Implications." Journal of Monetary Economics 21: 343-60.

McGratten, E. R. 1988. "The Macroeconomic Effects of Tax Policy in an Equilibrium Model." Stanford University Working Paper.

Nelson, C. and C. Plosser. 1982. "Trends and Random Walks in Macroeconomic Time Series: Some Evidence and Implications." Journal of Monetary Economics 10: 139-62.

Rogerson, R. E. 1988. "Indivisible Labor, Lotteries and Equilibrium." Journal of Monetary Economics 21: 3-16.

Schmookler, J. 1966. Invention and Economic Growth. Cambridge, Mass.: Harvard University Press.

Solow, R. M. 1957. "Technical Change and the Aggregate Production Function." Review of Economics and Statistics 39: 312-20.

\section{Comment}

PETER DIAMOND

I want to begin by introducing a simple one-sector model with the same characteristics as the basic model used by the authors. I found this alternate presentation helpful in understanding their model. Then I want to 
discuss the issue of co-movements across different industries and the relationship between co-movements and budget constraints. Third, I want to relate the model to the large gross flows of jobs and workers which exist in the U.S. economy.

\section{Basic Model}

Consider a static model with a continuum of identical agents. Each agent can work zero or one. Without work, there is no output. With work, output is either $x$ or $y, x<y$, depending on whether everyone else works or not. I will not worry about circumstances where only some of the population works, since this will not happen in the equilibria considered. I assume there are no other possible contacts between individuals except through the increasing returns to scale production externality. Utility is separable. With a suitable normalization, utility is equal to $U(0)$, $U(x)-1$, or $U(y)-1$, depending on the possible circumstances. We now assume that these values satisfy

$$
U(x)-1<U(0)<U(y)-1
$$

Then there are two equilibria, with everyone working and no one working. The two inequalities in (1) assure the presence of each of the equilibria.

Now consider stringing together a continuum of these static models. We have a dynamic rational expectations path with any time structure we would like for the choice between the two static equilibrium positions.

To get a little more structure on the range of possible outcomes, the next step is to modify preferences. (For an argument that the continuous time additive utility function does not have appealing properties, see Huang and Kreps 1987.) Following the authors' description of durables (which also can be interpreted as applying to non-durables), we write instantaneous utility as a function of a stock variable, $U(k)$, and have $k$ deteriorate at the exponential rate $d$ and grow at the rates $0, x$, or $y$ according to the level of output. We now let lifetime utility be the present discounted value of $U$, with utility discount rate $r$. Putting this structure into preferences rather than durability of the good avoids the embarrassment of having durability but not storability since inventories certainly complicate and may alter the equilibrium.

If the economy is always at the high output level, the consumption stock variable will converge to $y / d$. We assume that preferences are such that this is not an equilibrium. That is, we assume that someone with 
consumption stock $y / d$ and marginal product $y$ would choose not to work (for some interval of time) even if everyone else were continuing to work. In order to derive this condition, we need to derive the shadow value of $y$ units of output. The shadow value is equal to the present discounted value of the marginal utility of depreciated output given the time path of future production. Thus, we can rule out this steady state by assuming that the marginal utility of continued production, assuming indefinitely continued production, is less than the marginal disutility of work:

$\left.y U^{\prime}(y / d) / r+d\right)<1$

Similarly, we can rule out convergence to the origin by assuming that it is worth producing at zero stock even if no one else produces:

$x U^{\prime}(0) /(r+d)>1$

Thus this economy does not have a steady state with everyone behaving the same.

Considering only uniform behavior, the alternative equilibrium configuration has output alternately produced and not. As set up, there are many such paths as coordinated behavior among producers switches production on and off. These include what the authors call chattering paths with output switching on and off to keep the consumption stock constant. To cut down on the number of such paths, we could assume a fixed cost to beginning a production run. This would require modification of the conditions above to preserve the results. Someone contemplating the start of production at the origin would have to overcome the setup cost; someone considering a temporary stop to production at the high output steady state would have to save enough while stopped to overcome the fixed cost of starting up again. Similarly, equilibrium cycles would have to last long enough to justify the setup cost. These are technicalities, so I will not alter the assumptions.

Following the authors, let us focus on the cycle with the longest phases. To consider rational expectations paths, we shall consider the shadow price of a unit of output, which is denoted $p$. On a rational expectations path the value of a unit of consumption stock is the present discounted value of the marginal utility of the remaining (i.e., depreciated) stock. Differentiating this equation we have the familiar asset value differential equation.

$d p / d t=(r+d) p-U^{\prime}(k)$ 
This equation holds whether the good is being produced or not.

In Figures $1 a$ and $b$, we consider the phase diagrams with the shadow price of a unit of output on the vertical axis and the stock of consumer goods on the horizontal axis. We have two possible uniform behavior regimes. If everyone is producing, we have

$d k / d t=y-d k$

Alternatively, if no one is producing, we have

$d k / d t=-d k$

In both figures, I have drawn the stationary locus $d p / d t=0$. It is drawn to satisfy the two conditions, (2) and (3), that guarantee that there is not a steady state equilibrium. Thus the stationary locus is below $1 / y$ where it crosses $k=y / d$ and it is above $1 / x$ where it reaches the axis. Also drawn in are the directions of motion.

A rational expectations path satisfies the differential equations above, satisfying the appropriate equation for $d k / d t$ as production is or is not profitable given the behavior of other producers. It also satisfies the initial condition on the consumption stock variable, and a transversality condition on the shadow price.

In Figure 1a, we cannot go below the line $p=1 / y$, since that would contradict the profitability of production that makes Figure 1a the appropriate figure. In Figure $1 \mathrm{~b}$, we cannot go above the line $p=1 / x$. A rational expectations path spends some of its time in Figure 1a, and some of its time in Figure 1b. We consider only cycles that have precisely two phases, although one could construct more complicated paths with many different alternatively expanding and contracting phases before returning to the initial position, if ever. Since the rate of horizontal movement is independent of $p$ in each diagram, we will find the equilibrium cycle with the longest phases by looking for the one with the greatest width. This cycle has the two phases drawn in Figures 1a and $1 b$, where trajectories cross the stationary locus (and so are horizontal) as low and as high as possible. The entire cycle is shown in Figure 2.

To see that this is the cycle with the longest phases, let us first note that if production ceases to the left of the stationary locus, movement in Figure $1 \mathrm{~b}$ is then to the southwest. Second, we note that on any trajectory in Figure 1a which is to the left of the trajectory drawn, we cannot move to the right of the stationary locus since production must stop when the path crosses the horizontal line at $1 / y$. Thus, any point to the left of the trajectory drawn is not part of an equilibrium cycle. Similarly, 
Figure 1a: $d p / d t=(r+d) p-U^{\prime}(k)$

$$
d k / d t=y-d k
$$

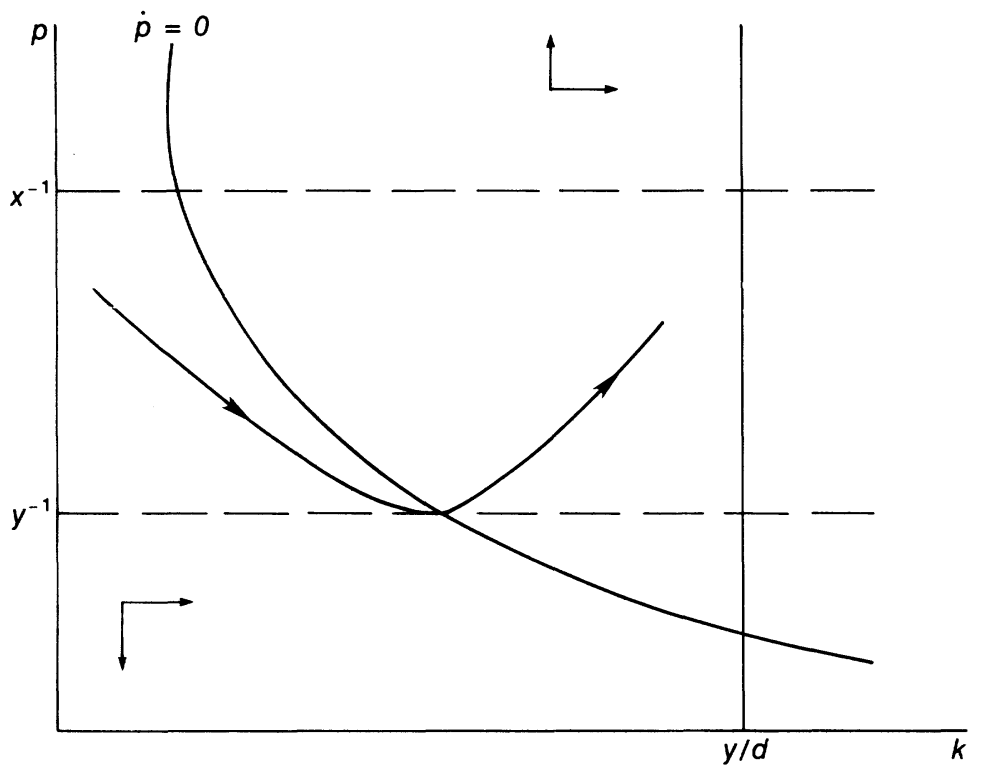

Figure 1b: $d p / d t=(r+d) p-U^{\prime}(k)$ $d k / d t=-d k$

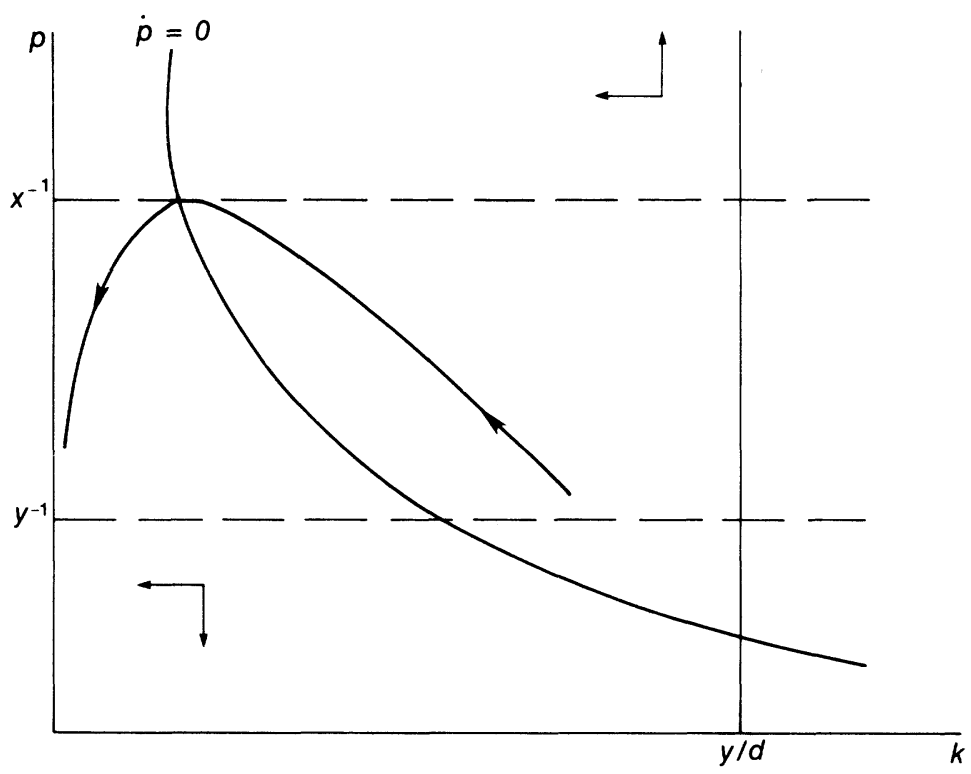


we note that movement in Figure 1a to the right of the stationary locus is to the northeast and that any path in Figure $1 \mathrm{~b}$ to the right of the drawn path cannot move to the left of the stationary locus. In Figure 2, we have concluded that some of the points outside the closed curve can not be part of a cyclic equilibrium. The remaining points outside the closed curve could be initial points for an equilibrium path, but are not points to which a rational expectations path could return. Thus the candidates for recurrent equilibria are on and inside the closed curve in Figure 2. Since the width of a path relates monotonically to the time on the path (over the same $k$ values), paths inside the cycle have shorter phases than those on the closed curve drawn. Inside the closed curve, every point is part of a continuum of equilibrium paths. All the chattering paths on the stationary locus inside the cycle are also equilibria.

What should we learn from this exercise? It is certainly possible to construct equilibrium cycles from increasing returns in production. Moreover, in such an exercise, the rational expectations paths are not unique, leaving an unreasonable scope for coordinated beliefs.

We have modeled this equilibrium as a non-market equilibrium with no interactions except for the production externality. It is interesting to ask whether there is a market economy with the same equilibria. That is, if we allow trading in consumer goods and labor, do there exist vectors

Figure 2

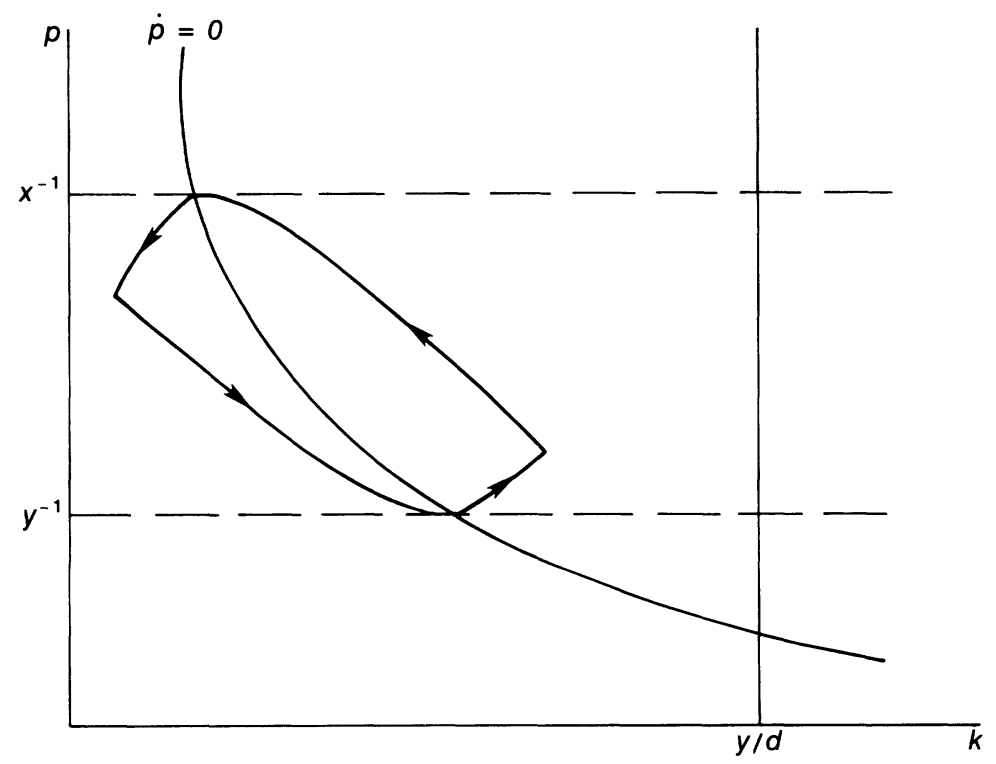


of consumer prices, wages, and interest rates such that there is no trade when everyone optimizes subject to a lifetime budget constraint? It appears that the answer is yes, with the wage as numeraire each moment of time, the price equal to the shadow price, and the interest rate equal to the utility discount rate. We need to assume a continuum of identical firms, each capable of hiring one worker, with more jobs than workers. Competition in the labor market then determines the real wage as the value of the marginal product of labor. Zero profits imply that firms are willing to produce or not, as desired, provided that they are coordinated. Workers want to provide labor when the wage is high and not otherwise. Consumers are content with the pattern of consumption by construction of the shadow price of a consumer good. Thus we have an equilibrium with lifetime budget constraints. The equilibrium has procyclical real wages.

\section{Co-movements}

Now let us consider two identical sectors, each as described above. If there is no connection between the sectors, there is no reason for the cycles to be the same in the two sectors. If we want to consider comovements, we need to link the sectors. The natural candidate for linkage is through demand. Let each consumer demand both goods (with additive utility from the two stocks), although production continues to be specialized. For now, assume that labor is immobile between sectors, so that demand is the only linkage. We continue to assume lifetime budget constraints. The equations above need to be changed slightly. Let us consider equilibria where consumption stocks of the two goods are the same vector for consumers working in the two sectors. Then, the pricing equation is unchanged. However, one's stock of one's own good only grows at the rate $y / 2-d k$ when production is positive. We assume that the figures are the same as drawn above after this change. Now, a perfectly coordinated cycle is an equilibrium with consumer goods trading one-for-one.

However, this is not the only equilibrium. Having each sector traverse the maximal cycle with any phasing between the two sectors is also an equilibrium. Relative consumer good prices are set by the stocks of the two consumer goods and would change over the cycle, but each consumer would be content to acquire half of whatever is being produced. (I assume that consumers in the two sectors have the same lifetime incomes even though they are out of phase.) Labor supply and production decisions satisfy the same condition as before. I have not considered whether the different sectors can traverse different cycles. Presumably 
they can under suitable conditions. It is clear that they can both be in the same cycle even if it is not the maximal cycle.

Now let us consider the implications of allowing perfectly mobile labor. First note that in the perfectly coordinated cycle, there is no reason to trade labor since the wage is the same in both sectors. However, increasing returns with greater labor inputs would tend to desynchronize production, because of the efficiency gains. Thus, labor mobility will tend to generate out-of-phase cycles as productivity shows even larger swings along with the larger swings in labor input. Labor mobility costs would work against desynchronization. So too would capacity constraints in the two sectors. However, capacity constraints are endogenous variables. I suspect that in many equilibria, aggregate capacity would exceed aggregate labor supply, permitting asynchronous movements. Thus, we must turn to limits on intertemporal budget constraints to make a stronger case for coordinated cycles. Thus this productionbased cycle theory needs demand conditions.

Again assuming immobile labor, let us turn to the other budgetary extreme, allowing only barter trade in newly produced consumer goods. (Thus consumers can not trade out of stocks.) Note that this is not only a limitation on borrowing, but also on saving. It is clear that the perfectly coordinated cycle remains an equilibrium. When both sectors are producing, the goods trade one for one. If only one sector were producing, there could be no trade. Thus it is clear that this budgetary assumption limits the extent to which the two markets can be out of phase. For example, we can no longer have the two sectors perfectly out of phase. To see this consider the case where the two phases have the same length. If the two sectors were perfectly out of phase, there could be no barter trade. Thus the stock of the "other" consumer good would be going to zero. At some point, this justifies production and trade even if no one else in your sector is producing (i.e., at productivity $x$ ).

It is natural to ask how much out of phase the two sectors can be. I have not considered this in detail. There is the complication of the terms of trade when there is a corner solution, with one of the sectors giving up all its current production in trade. I do want to describe one equilibrium cycle, assuming that trade is one for one. This will imply that when both sectors are producing, both will give up all their output for all the output of the other sector unless the marginal rates of substitution are the same in both sectors. In the example I will consider, positions will be symmetric during trade, so there is no problem with the assumption of one for one trade. We start with both sectors having the same equal stocks of both goods. At this point one of the sectors stops producing, with the other continuing to produce and adding its entire output to its 
stock of its own durable. After some time, the two sectors reverse positions. (Presumably, there could also be a time with both sectors shut down.) After some more time the sectors have equal levels of their own durables (and the sectors have equal levels of each other's durables). At this time both sectors produce, with all production going to the stocks of the other sector. This phase continues until we return to the initial point where all four stocks are equal. Pricing conditions will limit the lengths of the different portions of this cycle. On this equilibrium cycle, the correlation in production is approximately zero. It is precisely increasing returns which appears to make this cycle possible. With constant returns and barter, the sectors would both be on or both be off in this symmetric structure. Thus locating increasing returns in consumer trade, rather than just in production, appears to be an attractive part of this sort of model.

\section{Labor market flows}

In this model all firms behave the same. However, the labor market is marked by huge gross flows of labor (Abowd and Zellner 1985; Poterba and Summers 1986). Moreover there are huge gross flows of job creation and job destruction (Leonard 1988, Davis and Haltiwanger 1989). These facts raise two questions - the appropriateness of the labor immobility assumption which is critical for preventing the efficiency gains from desynchronization and the appropriateness of the real business cycle assumption that equilibrium is on the labor supply curve.

It is natural to ask whether one thinks that the basic increasing returns model could be fitted up to accommodate the facts of large gross flows. There would be no difficulty superimposing on the structure of this model a pattern of individual, idiosyncratic productivity shocks that generated a pattern of production starts and stops on an individual basis on top of the economy-wide moves (see, e.g., Blanchard and Diamond 1989). This would allow a diverse pattern of job creation and destruction. However, this modification implies a large available labor supply which makes the assumption of labor immobility very uncomfortable. The advantage of the increasing returns story is that demand swings will naturally move productivity together in all sectors. Thus some increasing returns in production are a plausible part of a cycle model. Such increasing returns alone are inadequate.

The model assumes that the economy is always on the labor supply curve. There are two ways to view this assumption. One is that the assumption is convenient, though unrealistic, while studying the workings of the other parts of the model. The alternative is to consider the assump- 
tion to be a plausible approximation to the workings of the labor market. The large gross flows imply that some people are working and some are not at all times. In order to induce the fluctuations in labor supply, the model needs (and has) procyclical real wage movements. Yet those who are unemployed at good times are choosing to take their time out of work at a time of high real wages. Of course, this can be partially rescued by a Lucas-Prescott (1974) unemployment while moving between jobs. However that model is not consistent with the widely varying durations of unemployment across individuals. Thus, I feel that the assumption that equilibrium occurs on the labor supply curve is an inaccurate interim assumption until we know how to build better models.

The bottom line is that we have one more way of consistently modeling cyclically varying profitability of production, if only we could explain why the labor market works as it does. That remains a basic puzzle.

\section{REFERENCES}

Abowd, John and Arnold Zellner. "Estimating the Gross Labor-Force Flows." Journal of Business and Economic Statistics 3-3, 254-283. July 1985.

Blanchard, Olivier Jean and Peter Diamond. "The Beveridge Curve." Brookings Papers on Economic Activity. Forthcoming.

Davis, Steve and John Haltiwanger. "Gross Job Creation, Gross Job Destruction, and Intrasectoral Labor Reallocation." Unpublished. 1989.

Huang, Chi-fu and David Kreps. "On Intertemporal Preferences with a Continuous Time Dimension, I: The Case of Certainty." MIT, Sloan School of Management Working Paper 1882, 1987.

Leonard, Jonathan S. "In the Wrong Place at the Wrong Time: The Extent of Frictional and Structural Unemployment." in Kevin Lang and Jonathan S. Leonard (eds.), Unemployment and the Structure of Labor Markets. London: Basil Blackwell, 1988.

Lucas Jr., Robert E. and Edward C. Prescott. "Equilibrium Search and Unemployment." Journal of Economic Theory 7: 188-209. 1974.

Poterba, James M. and Lawrence H. Summers. "Reporting Errors and Labor Force Dynamics." Econometrica 54-6: 1319-8. 1986.

\section{Discussion}

Kevin Murphy pointed out that heterogeneity of individuals suggests an upward sloping labor supply even in the Prescott model.

Valerie Ramey noted that the industrial organization and cost function literature tends to reject constant returns in favor of increasing returns to scale, with evidence of decreasing marginal cost. Bob Hall added that inventory data tends to suggest decreasing marginal cost. Ed Prescott stated that in real business cycle models inventory investment is not the 
problem, but that rather firm size and growth data tend to favor constant returns.

David Romer asked whether this model should be taken literally or metaphorically in light of the 1982 recession. Shleifer said that this is a model of propagation and dynamics, not shocks. Romer responded that the model predicts that the stock of durables would explain the duration of business cycles and asked if this was the case. Vishny said that it is hard to interpret the time series evidence on duration dependence.

Julio Rotemberg noted that if there were external economies, there would be no co-movement at the aggregate level. Murphy responded that there would be co-movement if specific sectors have varying amounts of external economies. Nobuhiro Kiyotaki stated that the authors should specify their matching and transactions technologies since the form of increasing returns has implications for persistence. 
